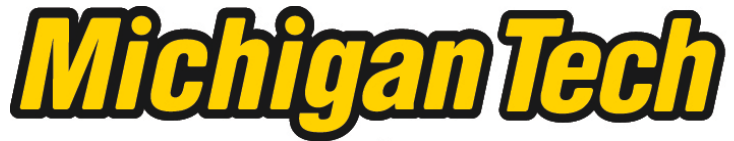 \\ Michigan Technological University Create the Future Digital Commons @ Michigan Tech
}

Dissertations, Master's Theses and Master's Reports - Open

Dissertations, Master's Theses and Master's

Reports

2005

\section{Effectiveness of a nondestructive evaluation technique for assessing standing timber quality}

Crystal L. Pilon

Michigan Technological University

Follow this and additional works at: https://digitalcommons.mtu.edu/etds

Part of the Forest Sciences Commons

Copyright 2005 Crystal L. Pilon

\section{Recommended Citation}

Pilon, Crystal L., "Effectiveness of a nondestructive evaluation technique for assessing standing timber quality", Master's Thesis, Michigan Technological University, 2005.

https://doi.org/10.37099/mtu.dc.etds/172

Follow this and additional works at: https://digitalcommons.mtu.edu/etds

8 Part of the Forest Sciences Commons 


\title{
EFFECTIVENESS OF A NONDESTRUCTIVE EVALUATION TECHNIQUE FOR ASSESSING STANDING TIMBER QUALITY
}

\author{
By \\ Crystal L. Pilon

\begin{abstract}
A THESIS
Submitted in partial fulfillment of the requirements

for the degree of

MASTER OF SCIENCE IN FORESTRY
\end{abstract}

MICHIGAN TECHNOLOGICAL UNIVERSITY

2005

Copyright $($ C Crystal L. Pilon 2005 
This thesis, "Effectiveness of a Nondestructive Evaluation Technique For Assessing Standing Timber Quality," is hereby approved in partial fulfillment of the requirements for the Degree of MASTER OF SCIENCE IN FORESTRY.

School of Forest Resources and Environmental Science

Dean: Margaret R. Gale

Thesis Co-Advisors: $\quad$ Margaret R. Gale, John R. Erickson

Committee Members: John B. Ligon, Robert J. Ross, Xiping Wang

Date: October 4, 2005 


\section{Acknowledgements}

The author would like to express sincere thanks to Dr. Margaret R. Gale and John R. Erickson for taking on the duties of committee co-chairs and providing invaluable advice and support. She would also like to express sincere gratitude to Dr. Robert J. Ross for providing encouragement and guidance during the thesis research and writing process. Dr. Xiping Wang and Dr. John B. Ligon, graduate committee members, have offered support and advice throughout the study.

Peter Carter, from fibre-gen, has generously provided equipment, support and data necessary for the success of this study. A special note of thanks is extended to James T. Gilbertson for his indispensable help in the testing process. Special acknowledgement is also noted for support from the U.S.D.A. Forest Service Forest Products Laboratory. 


\section{Effectiveness of a Nondestructive Evaluation Technique For}

Assessing Standing Timber Quality

Crystal L. Pilon

October 4, 2005

\section{(ABSTRACT)}

The research presented in this thesis was conducted to further the development of the stress wave method of nondestructively assessing the quality of wood in standing trees. The specific objective of this research was to examine, in the field, use of two stress wave nondestructive assessment techniques.

The first technique examined utilizes a laboratory-built measurement system consisting of commercially available accelerometers and a digital storage oscilloscope. The second technique uses a commercially available tool that incorporates several technologies to determine speed of stress wave propagation in standing trees.

Field measurements using both techniques were conducted on sixty red pine trees in south-central Wisconsin and 115 ponderosa pine trees in western Idaho. After in-situ measurements were taken, thirty tested red pine trees were felled and a 15-foot-long butt log was obtained from each tree, while all tested ponderosa pine trees were felled and an $81 / 2$-foot-long butt log was obtained, respectively. The butt logs were sent to the USDA Forest Products Laboratory and nondestructively tested using a resonance stress wave 
technique. Strong correlative relationships were observed between stress wave values obtained from both field measurement techniques. Excellent relationships were also observed between standing tree and log speed-of-sound values.

Copyright @ Crystal L. Pilon 2005 


\section{Table of Contents}

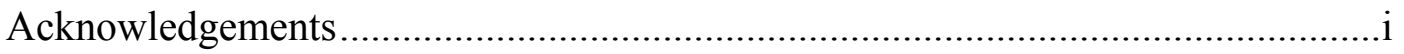

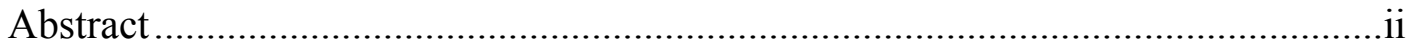

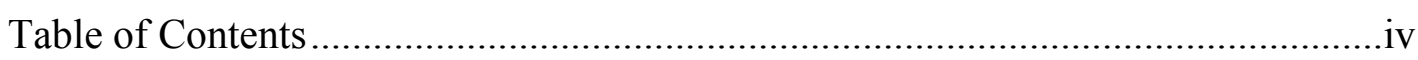

List of Tables .........................................................................................

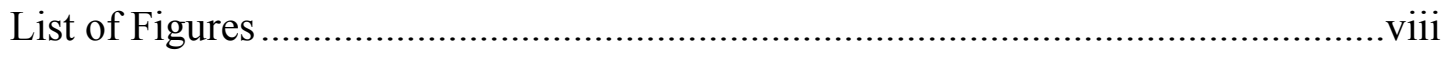

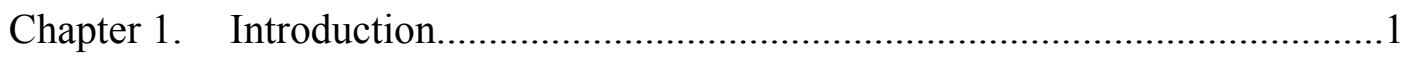

Chapter 2. Literature Review .....................................................................

2.1 Stress wave propagation .............................................. 3

2.2 Longitudinal stress wave nondestructive evaluation ................4

2.3 Longitudinal stress wave nondestructive evaluation of standing trees ............................................ 8

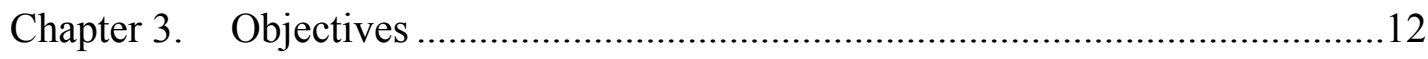

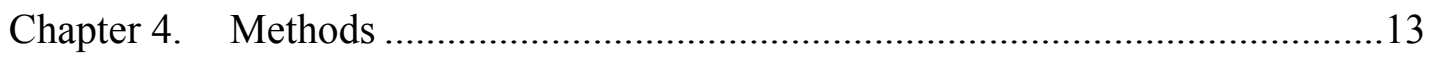

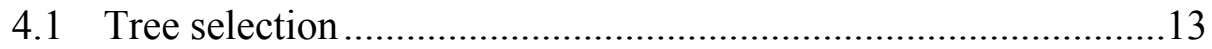

4.2 Experimental techniques.................................................15

4.2.1. Laboratory-based equipment ..................................15

4.2.2. Commercial tree assessment tool ...............................16

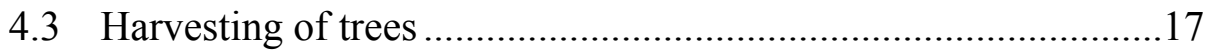

4.4 Laboratory evaluation of $\log$............................................ 18

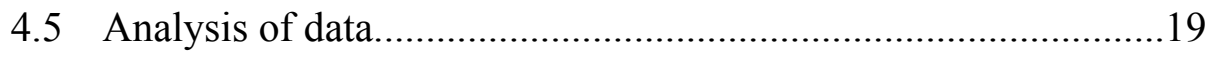




\section{Table of Contents (cont.)}

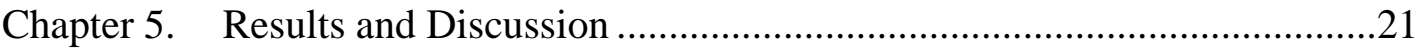

5.1 Statistical relationship between laboratory-based method and commercial tree assessment tool (red pine and ponderosa pine) (........................................................21

5.2 Relationship between standing tree and log evaluation (red pine and ponderosa pine) ..................................................23

5.3 Statistical relationship of trees and logs (worldwide

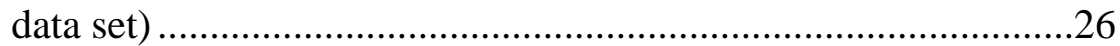

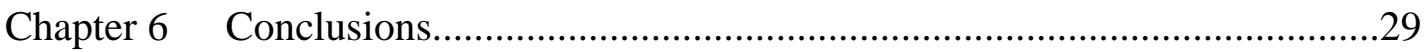

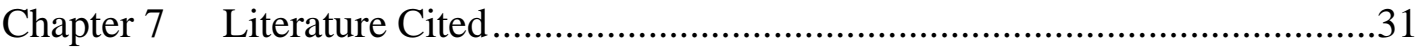

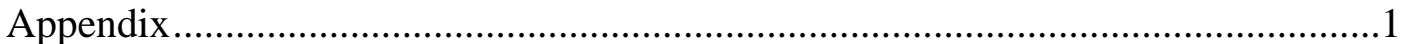




\section{List of Tables}

Table 1. Nondestructive evaluation techniques used to evaluate woodbased materials (Pellerin and Ross 1994, Bucur 1985). .2

Table 2. Summary of past research on nondestructive stress wave testing on lumber and wood composite products (Pellerin and Ross 2002) .6

Table 3. Research summary of correlation between nondestructive testing parameters and properties of degraded wood (Pellerin and Ross 2002).

Table 4. Summary of past research on nondestructive evaluation of standing trees using longitudinal stress-wave methods (Pellerin and Ross 2002). .8

Table 5. Diameter classes of ponderosa pine trees......................................... 15

Table 6. Diameter classes of ponderosa pine logs sent to the USDA Forest Products Laboratory (Madison, WI) for further testing.

Table 7. Nondestructive evaluation techniques used to evaluate woodbased materials (Pellerin and Ross 1994, Bucur 1985).

Table 8. Relationship of stress wave speed in red pine and ponderosa pine trees using the commercial tree assessment tool $(\mathrm{Y})$ and logs using resonance-based stress wave technique (X). .25 


\section{List of Tables (cont.)}

Table 9. Relationships between stress-wave speed of trees and logs using the commercial tree assessment tool and laboratory-

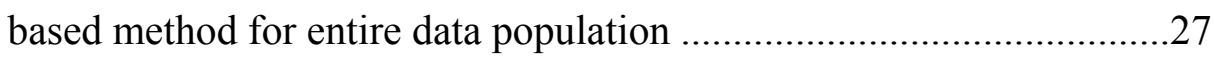

Table 10. Data bank of relationships between stress-wave speed of trees and logs using the commercial tree assessment tool and laboratory-based method .28 


\section{List of Figures}

Figure 1. Illustration of stress wave propagation and measurement on

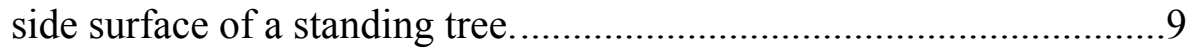

Figure 2. Typical waveforms observed by Wang (1999).................................. 10

Figure 3. Nondestructive testing of trees followed by nondestructive

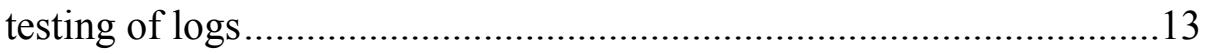

Figure 4. Wisconsin red pine trees (Arena, WI)........................................... 14

Figure 5. Idaho ponderosa pine trees (Boise National Forest, ID)......................14

Figure 6. Illustration of stress wave propagation and measurement on

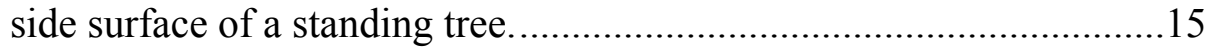

Figure 7. Accelerometer clamped onto a spike embedded into stem at $45^{\circ}$ to grain. 16

Figure 8. Start and stop signals from accelerometers shown on oscilloscope. .16

Figure 9. Setup of commercial tree assessment tool includes speciallydesigned probes and a PDA for wireless data collection.

Figure 10. Travel of compression wave along log. The forward-moving wave impinges on the free end of the log, is reflected as a tensile wave, and begins to travel back down the log (Pellerin and Ross 2002). 


\section{List of Figures (cont.)}

Figure 11. Log acoustic properties measured with a resonance stress wave technique using the Director HM200.

Figure 12. Determining acoustic properties of red pine logs with Director HM200 (fibre-gen, Auckland, New Zealand).

Figure 13. Relationship of stress wave speed in red pine and ponderosa pine trees using the laboratory stress wave method and the commercial tool. 23

Figure 14. Relationship of stress wave speed of trees and logs using data from the commercial tool and the log resonance stress wave technique.

Figure 15. Data bank of stress-wave analysis on logs and standing trees using the commercial tree assessment tool and laboratorybased method. 


\section{Chapter 1 Introduction}

Our forests are an extremely valuable resource. In addition to aesthetic and recreational value, our forests serve as a renewable source of raw material for an ever-increasing list of wood and fiber products. Wood is a highly variable material because of the stresses placed upon it by wind, weather, and genetics. Also, wood properties vary due to forest management regimes and soil composition. As a result, manufacturers and users of wood products are frequently frustrated when using wood because its properties can vary significantly (Brown et al. 1952). Manufacturers of wood products find it difficult to manufacture products with consistent properties, and users of wood products find that wood products are often subject to performance variability (Wang 1999).

Nondestructive evaluation (NDE) technologies have contributed significantly toward eliminating these inconsistencies (Bertholf 1965, Ross 1985, Kaiserlik and Pellerin 1977). By definition, NDE is the process of identifying the physical and mechanical properties of a material without altering its end-use capabilities and using this information to make decisions regarding appropriate applications. The development of NDE technologies and their use with wood has resulted in an increase in engineered wood-based materials that have well-defined performance characteristics. Various NDE technologies are used with wood-based materials, including those that utilize x-rays, chemical analyses, vibration properties, and sound transmission characteristics (Table 1, Ross and Pellerin 1994, Bucur 1985). Whereas most of these techniques are useful for determining wood properties, they are not always cost-effective and most cannot be used effectively in the field (Schad et al. 1996). 
Table 1. Nondestructive evaluation techniques used to evaluate wood-based materials (Pellerin and Ross 1994, Bucur 1985).

\begin{tabular}{|c|c|}
\hline \multicolumn{2}{|c|}{ Nondestructive Evaluation of Wood } \\
\hline $\begin{array}{l}\text { Evaluation of visual } \\
\text { characteristics }\end{array}$ & Chemical tests \\
\hline Color & Composition \\
\hline Presence of defects & $\begin{array}{cl}\text { Presence of treatments } \\
\bullet \quad \text { Preservatives } \\
\bullet \quad \text { Fire retardants }\end{array}$ \\
\hline Physical tests & Mechanical tests \\
\hline Electrical resistance & Flexural stiffness \\
\hline Dielectric properties & Proof loading \\
\hline Vibrational properties & Bending \\
\hline Wave propagation & Tension \\
\hline Acoustic emissions & Compression \\
\hline X-ray & Probes/coring \\
\hline
\end{tabular}

Currently, there is a strong interest in the development and use of a variety of NDE technologies to aid in the assessment of standing timber. Traditionally, trees have been selected for harvest on the basis of their visual characteristics (Green 1997). While visually assessing trees is useful for estimating the quality of wood in a tree, the assumption that visual tree characteristics are correlated to mechanical properties of the wood in a tree is not always reliable.

One technique that has been investigated as an aid in the evaluation of the quality of wood in standing timber uses sound transmission characteristics (Pellerin and Ross 2002). Research has shown, for example, that the speed at which a wave travels in wood is 1) dependent upon fiber angle (Kaiserlik and Pellerin 1977), 2) influenced significantly by the presence of certain types of decay or deterioration (Pellerin et al. 1985), and 3) influenced by the presence of knots (Gerhards 1981, 1982), all of which are important factors in determining timber quality. Stress-wave attenuation (or the rate at which a wave loses energy as it travels through wood) is another parameter that correlates with wood properties. 


\section{Chapter 2 Literature Review}

\subsection{Stress Wave Propagation}

Different types of elastic waves can propagate in solids, depending on how the motion of the particles of the solid is related to the direction of propagation of the waves themselves and on the boundary conditions. The following is a summary of the various wave types in solids as summarized by Meyers (1994).

\section{Longitudinal Waves (P Waves)}

Longitudinal waves correspond to the motion of the particles back and fourth along the direction of wave propagation such that particle motion is parallel to wave motion. Longitudinal waves that travel in three dimensions are known as dilatational waves.

\section{Shear Waves (Distortional Waves)}

For shear waves, motion of the particles conveying the wave are perpendicular to the direction of the propagation of the wave. These waves are also referred to as distortional or transverse waves.

3. Surface Waves (Rayleigh Waves)

Surface waves in solids (also referred to as Rayleigh waves) are analogous to waves on the surface of water. The particles move both up and down and back and forth, tracing out elliptical paths as the surface wave moves by. This type of 
wave is restricted to the region adjacent to the surface, and "particle" velocity $\left(U_{p}\right)$ decreases very rapidly as the wave moves by.

4. Interfacial Waves (Stoneley Waves)

When two semi-infinite media with different properties are in contact, these special waves form at their interface.

5. Waves in Layered Media (Love Waves)

Named after the first person to study them (Love 1944), these wave types occur in layered media with different properties. For Love waves, the horizontal component of displacement can be significantly larger than the vertical component, a behavior not consistent with Rayleigh waves.

6. Bending (Flexural) Waves

These waves involve propagation of flexure in a one-dimensional (bar) or twodimensional configuration.

Among all these types of waves, longitudinal waves travel fastest and are most commonly used in property evaluation and defect detection.

\subsection{Longitudinal Stress Wave Nondestructive Evaluation}

The propagation of longitudinal $(\mathrm{P})$ waves in solids is influenced in a complex manner by both the mechanical and physical properties of the medium (Jayne 1959, Pellerin 1965, 
Bertholf 1965, Kaiserlik 1977, Ross 1985). To describe the propagation of longitudinal stress waves for practical use, the complex expressions are commonly simplified to elementary, one-dimensional wave propagation theory as applied to an isotropic homogeneous material. For specimens that have lateral dimensions which are small compared with the wavelength of the propagating wave, this simplified theory yields the following equation relating the speed of propagation, $\mathrm{C}$, to modulus of elasticity, MOE, and mass density, $\rho$ (Pellerin and Ross 2002).

$$
C=\sqrt{\frac{M O E}{\rho}}
$$

The usefulness of this theory for wood could be considered dubious since wood and wood products are neither isotropic nor homogeneous (Brown et al. 1952). Research results, however, have shown that the propagation rate of stress waves is a good indicator of the quality of the wood through which the wave propagates (Tables 2 and 3). 
Table 2. Summary of past research on nondestructive stress wave testing on lumber and wood composite products (Pellerin and Ross 2002).

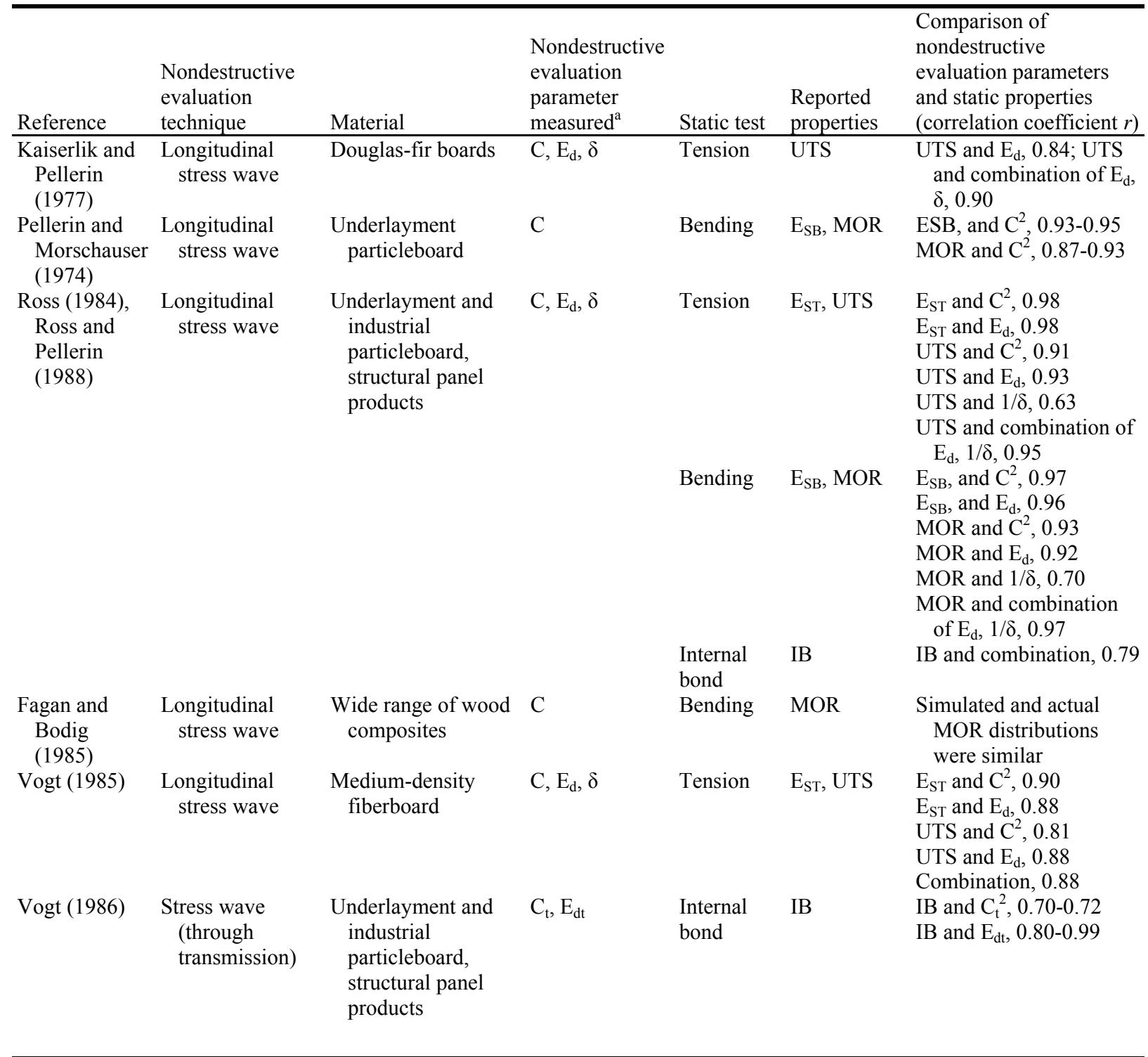

${ }^{a} \mathrm{C}$, speed of sound; $\mathrm{C}_{t}$, speed-of-sound transmission through thickness; $\delta$, logarithmic decrement; $\mathrm{E}_{\mathrm{d}}$, dynamic modulus of elasticity (MOE) from transverse vibration or stress-wave measurements; $E_{\mathrm{dt}}$, dynamic MOE through thickness orientation; $\mathrm{E}_{\mathrm{SB}}, \mathrm{MOE}$ from static bending test; $\mathrm{E}_{\mathrm{ST}}$, MOE from static tension test; IB, internal bond; MOR, modulus of rupture; UTS, ultimate tensile stress. 
Table 3. Research summary of correlation between nondestructive testing parameters and properties of degraded wood (Pellerin and Ross 2002).

\begin{tabular}{|c|c|c|c|c|c|c|c|}
\hline Reference & NDE technique & Material & $\begin{array}{l}\text { Degradation } \\
\text { agent }\end{array}$ & $\begin{array}{l}\text { NDE } \\
\text { parameter } \\
\text { measured }^{\mathrm{a}}\end{array}$ & Static test & $\begin{array}{l}\text { Reported } \\
\text { properties }\end{array}$ & $\begin{array}{l}\text { Comparison of NDE parameters } \\
\text { and static properties (correlation } \\
\text { coefficient } r \text {, unless noted) }\end{array}$ \\
\hline $\begin{array}{r}\text { Chudnoff et } \\
\text { al. (1984) }\end{array}$ & $\begin{array}{l}\text { Longitudinal } \\
\text { stress wave } \\
\text { (parallel to } \\
\text { grain) }\end{array}$ & $\begin{array}{l}\text { Decayed } \\
\text { and sound } \\
\text { mine } \\
\text { props; } 26 \\
\text { species or } \\
\text { species } \\
\text { groupings }\end{array}$ & - & $\mathrm{E}_{\mathrm{d}}$ & $\begin{array}{l}\text { Compression } \\
\text { parallel to } \\
\text { grain }\end{array}$ & $\mathrm{E}_{\mathrm{c}}, \mathrm{UCS}$ & $\begin{array}{l}\mathrm{E}_{\mathrm{c}} \text { and } \mathrm{E}_{\mathrm{d}}, 0.84-0.97 \text { (all species } \\
\text { combined, hardwoods, maple, } \\
\text { and oaks) } \\
\mathrm{E}_{\mathrm{c}} \text { and } \mathrm{E}_{\mathrm{d}}, 0.73-0.81 \text { (all species } \\
\text { combined, southern pines, } \\
\text { lodgepole pine) } \\
\text { UCS and } \mathrm{E}_{\mathrm{d}}, 0.85-0.95 \text { (all } \\
\text { species combined, } \\
\text { hardwoods, maple, and oaks) }\end{array}$ \\
\hline \multirow[t]{2}{*}{$\begin{array}{l}\text { Pellerin et } \\
\text { al. (1985) }\end{array}$} & $\begin{array}{l}\text { Longitudinal } \\
\text { stress wave } \\
\text { (parallel to } \\
\text { grain) }\end{array}$ & $\begin{array}{l}\text { Small clear } \\
\text { southern } \\
\text { yellow } \\
\text { pine } \\
\text { specimens }\end{array}$ & $\begin{array}{l}\text { Brown-rot fungi } \\
\text { (Gloeophyllum } \\
\text { trabeum) }\end{array}$ & $\mathrm{C}, \mathrm{E}_{\mathrm{d}}$ & $\begin{array}{l}\text { Compression } \\
\text { parallel to } \\
\text { grain }\end{array}$ & UCS & $\begin{array}{l}\text { UCS and C: } \\
0.47 \text { (control) } \\
0.73 \text { (exposed) } \\
0.80 \text { (control and exposed) } \\
\text { UCS and } E_{\mathrm{d}} \text { : } \\
0.86 \text { (control) } \\
0.86-0.89 \text { (exposed) } \\
0.94 \text { (control and exposed) }\end{array}$ \\
\hline & & & $\begin{array}{l}\text { Termites } \\
\quad \text { (subterranean) }\end{array}$ & $\mathrm{C}, \mathrm{E}_{\mathrm{d}}$ & $\begin{array}{l}\text { Compression } \\
\text { parallel to } \\
\text { grain }\end{array}$ & UCS & $\begin{array}{l}\text { UCS and C: } \\
0.65 \text { (control) } \\
0.21 \text { (exposed) } \\
0.28 \text { (control and exposed) } \\
\text { UCS and } E_{\mathrm{d}} \text { : } \\
0.90 \text { (control) } \\
0.79 \text { (exposed) } \\
0.80 \text { (control and exposed) }\end{array}$ \\
\hline $\begin{array}{l}\text { Rutherford } \\
\text { (1987), } \\
\text { Rutherford } \\
\text { et al. } \\
\text { (1987) }\end{array}$ & $\begin{array}{l}\text { Longitudinal } \\
\text { stress wave } \\
\text { (perpendicular } \\
\text { to grain) }\end{array}$ & $\begin{array}{l}\text { Small, clear } \\
\text { Douglas- } \\
\text { fir } \\
\text { specimens }\end{array}$ & $\begin{array}{l}\text { Brown-rot fungi } \\
\text { (Gloeophyllum } \\
\text { trabeum) }\end{array}$ & $\mathrm{C}, \mathrm{E}_{\mathrm{d}}$ & $\begin{array}{l}\text { Compression } \\
\text { perpendicular } \\
\text { to grain }\end{array}$ & $\mathrm{E}_{\mathrm{c}}, \mathrm{UCS}$ & $\begin{array}{l}E_{\mathrm{c}} \text { and } \mathrm{C}, 0.91 \\
\mathrm{E}_{\mathrm{c}} \text { and } \mathrm{E}_{\mathrm{d}}, 0.94 \\
\mathrm{UCS} \text { and } \mathrm{C}, 0.67-0.70 \\
\mathrm{UCS} \text { and } \mathrm{E}_{\mathrm{d}}, 0.79 \\
\text { UCS and MOE, } 0.80\end{array}$ \\
\hline $\begin{array}{l}\text { Patton- } \\
\text { Mallory } \\
\text { and De } \\
\text { Groot } \\
(1989)\end{array}$ & $\begin{array}{l}\text { Longitudinal } \\
\text { stress wave }\end{array}$ & $\begin{array}{l}\text { Small, clear } \\
\text { southern } \\
\text { yellow } \\
\text { pine } \\
\text { specimens }\end{array}$ & $\begin{array}{l}\text { Brown-rot fungi } \\
\text { (Gloeophyllum } \\
\text { trabeum) }\end{array}$ & $\begin{array}{l}\text { C, root } \\
\text { mean } \\
\text { square } \\
\text { Voltage } \\
\text { frequency } \\
\text { Content of } \\
\text { received } \\
\text { signal }\end{array}$ & Bending & $\begin{array}{l}\text { Maximum } \\
\text { moment, } \\
\text { alkali } \\
\text { solubility }\end{array}$ & $\begin{array}{l}\text { Linear decrease in } \mathrm{C} \text { and } \\
\text { decrease in signal strength } \\
\text { with increased wood } \\
\text { degradation } \\
\text { High-frequency components of } \\
\text { signal attenuated in very early } \\
\text { stages of decay. }\end{array}$ \\
\hline $\begin{array}{l}\text { Ross et al. } \\
\quad(1992)\end{array}$ & $\begin{array}{l}\text { Longitudinal } \\
\text { stress wave } \\
\text { (perpendicular } \\
\text { to grain) }\end{array}$ & $\begin{array}{l}\text { Red oak and } \\
\text { white oak } \\
\text { lumber }\end{array}$ & $\begin{array}{l}\text { Bacteria } \\
\text { (Clostridium } \\
\text { and Erwinia } \\
\text { sp.) }\end{array}$ & $\mathrm{C}$ & None & $\begin{array}{l}\text { Presence of } \\
\text { infection }\end{array}$ & $\begin{array}{l}\text { Decrease in } \mathrm{C} \text { with presence of } \\
\text { infection }\end{array}$ \\
\hline $\begin{array}{l}\text { Verkasalo et } \\
\text { al. (1993) }\end{array}$ & $\begin{array}{l}\text { Longitudinal } \\
\text { stress wave } \\
\text { (perpendicular } \\
\text { to grain) }\end{array}$ & $\begin{array}{l}\text { Red oak } \\
\text { lumber }\end{array}$ & $\begin{array}{l}\text { Bacteria } \\
\text { (Clostridium } \\
\text { and Erwinia } \\
\text { sp.) }\end{array}$ & $\mathrm{C}$ & $\begin{array}{l}\text { Tension } \\
\text { perpendicular } \\
\text { to grain }\end{array}$ & $\begin{array}{l}\text { UTS, } \\
\text { presence } \\
\text { of } \\
\text { infection }\end{array}$ & $\begin{array}{l}\text { Decrease in C and UTS with } \\
\text { presence of infection }\end{array}$ \\
\hline
\end{tabular}

\footnotetext{
${ }^{a} \mathrm{AE}$, acoustic emission; $\mathrm{C}$, speed of sound; $\mathrm{E}_{\mathrm{c}}$, modulus of elasticity (MOE) from static compression test; $\mathrm{E}_{\mathrm{d}}$, dynamic MOE from transverse vibration or stress wave measurements; MOR, modulus of rupture; UCS, ultimate compressive stress; UTS, ultimate tensile stress.
} 


\title{
2.3 Longitudinal stress wave nondestructive evaluation of standing trees
}

\author{
A summary of research studies conducted to examine the use of longitudinal stress waves \\ for evaluating standing trees is shown in Table 4.
}

Table 4. Summary of past research on nondestructive evaluation of standing trees using longitudinal stresswave methods (Pellerin and Ross 2002).

\begin{tabular}{|c|c|c|c|c|}
\hline Reference & Tree species & $\begin{array}{l}\text { Nondestructive } \\
\text { evaluation } \\
\text { parameter }^{\mathrm{a}}\end{array}$ & $\begin{array}{l}\text { Reported } \\
\text { properties }\end{array}$ & $\begin{array}{l}\text { Comparison of } \\
\text { nondestructive evaluation } \\
\text { parameter of trees and } \\
\text { reported properties } \\
\text { (correlation coefficient } r \text { ) }\end{array}$ \\
\hline Nanami et al. (1992) & Japanese cedar & $\Delta \mathrm{T}$ & $\Delta \mathrm{T}$ in logs & $\begin{array}{l}\text { Good agreement ( } r \text { was not } \\
\text { reported) }\end{array}$ \\
\hline Nanami et al. (1993) & Japanese cedar & $\mathrm{C}$ & $\mathrm{MOE}_{\mathrm{d}}$ of trees & 0.77 \\
\hline Nakamura (1996) & Todo-fir and larch & $\mathrm{C}^{2}$ & $\mathrm{MOE}_{\mathrm{d}}$ of trees & 0.94 \\
\hline \multirow[t]{4}{*}{$\begin{array}{l}\text { Wang (1999), Wang et al. } \\
\quad(2000 \mathrm{~b})\end{array}$} & $\begin{array}{l}\text { Western hemlock } \\
\text { and Douglas-fir }\end{array}$ & $\mathrm{C}$ & $\begin{array}{l}\mathrm{C} \text { of small clear } \\
\text { specimens }\end{array}$ & 0.83 \\
\hline & & $\mathrm{MOE}_{\mathrm{d}}$ & $\begin{array}{l}\mathrm{MOE}_{\mathrm{d}} \text { of small } \\
\text { clear specimens }\end{array}$ & 0.75 \\
\hline & & $\mathrm{MOE}_{\mathrm{d}}$ & $\begin{array}{l}\mathrm{MOE}_{\mathrm{s}} \text { of small } \\
\text { clear specimens }\end{array}$ & 0.66 \\
\hline & & $\mathrm{MOE}_{\mathrm{d}}$ & $\begin{array}{l}\text { MOR of small } \\
\text { clear specimens }\end{array}$ & $\begin{array}{l}0.65 \text { (western hemlock) } \\
0.63 \text { (Sitka spruce) }\end{array}$ \\
\hline Huang (2000) & Loblolly pine & $\mathrm{C}$ & $\mathrm{MOE}_{\mathrm{v}}$ of lumber & 0.71 \\
\hline Ikeda and Kino (2000) & Japanese cedar & $\mathrm{C}$ & $\mathrm{MOE}_{\mathrm{d}}$ of logs & 0.56 \\
\hline \multirow[t]{2}{*}{ Ikeda and Arima (2000) } & Japanese cedar & $\mathrm{C}$ & $\mathrm{MOE}_{\mathrm{d}}$ of $\log$ & $0.61-0.68$ \\
\hline & & $\mathrm{C}$ & $\begin{array}{l}\mathrm{MOE}_{\mathrm{s}} \text { of square } \\
\text { timber }\end{array}$ & 0.64 \\
\hline \multirow[t]{2}{*}{ Ikeda et al. (2000b) } & Japanese cedar & $\mathrm{C}$ & $\mathrm{MOE}_{\mathrm{d}}$ of $\log \mathrm{s}$ & 0.56 \\
\hline & & $\mathrm{C}$ & $\begin{array}{l}\text { Mean } \mathrm{MOE}_{\mathrm{d}} \text { of } \\
\text { logs }\end{array}$ & $0.74-0.94$ \\
\hline Ikeda et al. (2000a) & Hinoki & $\mathrm{C}$ & $\mathrm{MOE}_{\mathrm{d}}$ of logs & $0.64-0.80$ \\
\hline \multirow[t]{3}{*}{ Wu et al. (2000) } & Douglas-fir & $\mathrm{C}_{\mathrm{L}}$ & $\mathrm{MOE}_{\mathrm{v}}$ of lumber & 0.88 \\
\hline & & $\mathrm{C}_{\mathrm{R}}$ & $\mathrm{MOE}_{\mathrm{v}}$ of lumber & 0.62 \\
\hline & & $\mathrm{C}_{\mathrm{L}}^{2} \mathrm{C}_{\mathrm{R}}^{2}$ & $\mathrm{MOE}_{\mathrm{v}}$ of lumber & 0.93 \\
\hline \multirow[t]{4}{*}{ Wang et al. (2001b) } & $\begin{array}{l}\text { Western hemlock } \\
\text { and Sitka spruce }\end{array}$ & $\mathrm{C}$ & $\begin{array}{l}\text { C of small clear } \\
\text { specimens }\end{array}$ & 0.83 \\
\hline & & $\mathrm{MOE}_{\mathrm{d}}$ & $\begin{array}{l}\mathrm{MOE}_{\mathrm{d}} \text { of small } \\
\text { clear specimens }\end{array}$ & 0.75 \\
\hline & & $\mathrm{MOE}_{\mathrm{d}}$ & $\begin{array}{l}\mathrm{MOE}_{\mathrm{s}} \text { of small } \\
\text { clear specimens }\end{array}$ & 0.66 \\
\hline & & $\mathrm{MOE}_{\mathrm{d}}$ & $\begin{array}{l}\text { MOR of small } \\
\text { clear specimens }\end{array}$ & $\begin{array}{l}0.65 \text { (western hemlock) } \\
0.63 \text { (Sitka spruce) }\end{array}$ \\
\hline
\end{tabular}

\footnotetext{
${ }^{\mathrm{a}} \Delta \mathrm{T}$, wave propagation time; $\mathrm{C}, \mathrm{C}_{\mathrm{L}}$, stress wave speed in longitudinal direction; $\mathrm{C}_{\mathrm{R}}$, stress wave speed in radial direction; $\mathrm{MOE}_{\mathrm{d}}$, dynamic modulus of elasticity determined by stress wave method; $\mathrm{MOE}_{\mathrm{v}}$, modulus of elasticity determined by transverse vibration method; $\mathrm{MOE}_{\mathrm{s}}$, modulus of elasticity obtained from static bending tests; MOR, modulus of rupture obtained from static bending tests.
}

Of particular significance are the results of a study conducted by Wang (1999, 2000a). He developed the technique illustrated in Figure 1 and used it to evaluate, in the field, the 
properties of western hemlock and Sitka spruce trees. His technique utilized two spikes that were inserted into the tree at $45^{\circ}$ to the bark surface, one at each end of a $4-\mathrm{ft}$ span. Accelerometers were attached to the spikes using specially designed clamps. One spike was impacted to send the stress wave through the tree. The longitudinal wave propagated along the stem, and its passing sensed by the accelerometers, sending a signal to an oscilloscope (Figure 2). Stress-wave travel time was determined by locating the two starting points in the resulting waveform using the following equation:

$$
\Delta \mathrm{t}=\mathrm{t}_{2}-\mathrm{t}_{1}
$$

where:

$$
\begin{aligned}
& \Delta \mathrm{t}=\text { stress-wave transmission time } \\
& \mathrm{t}_{1}=\text { time where first waveform rises, and } \\
& \mathrm{t}_{2}=\text { time where second waveform rises }
\end{aligned}
$$

Figure 1. Illustration of stress wave propagation and measurement on side surface of a standing tree.

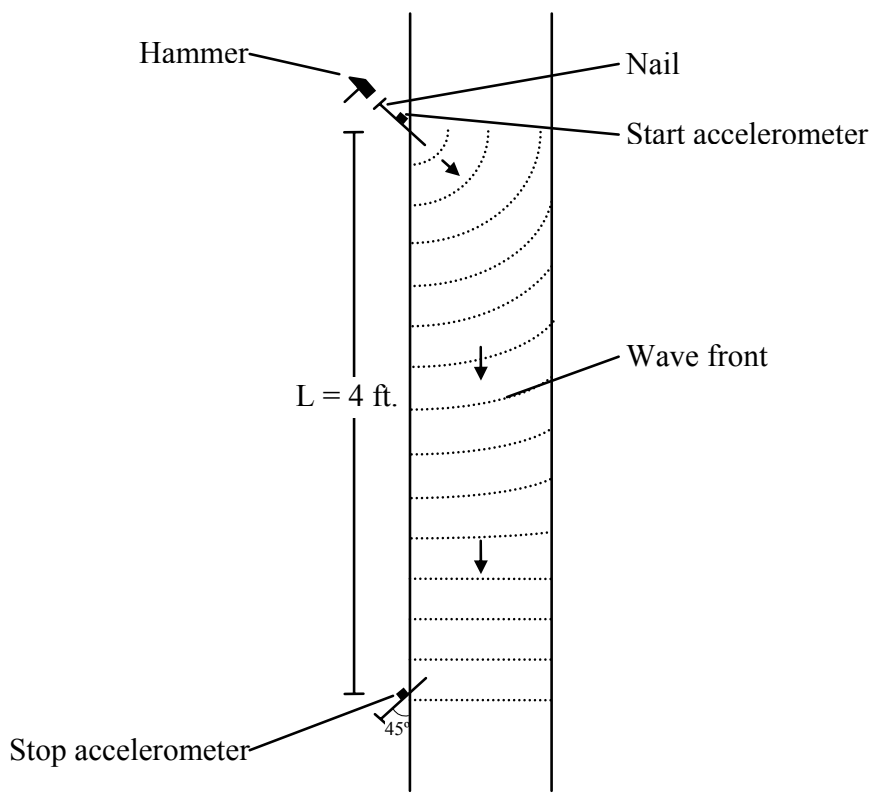


Figure 2. Typical waveforms observed by Wang (1999).

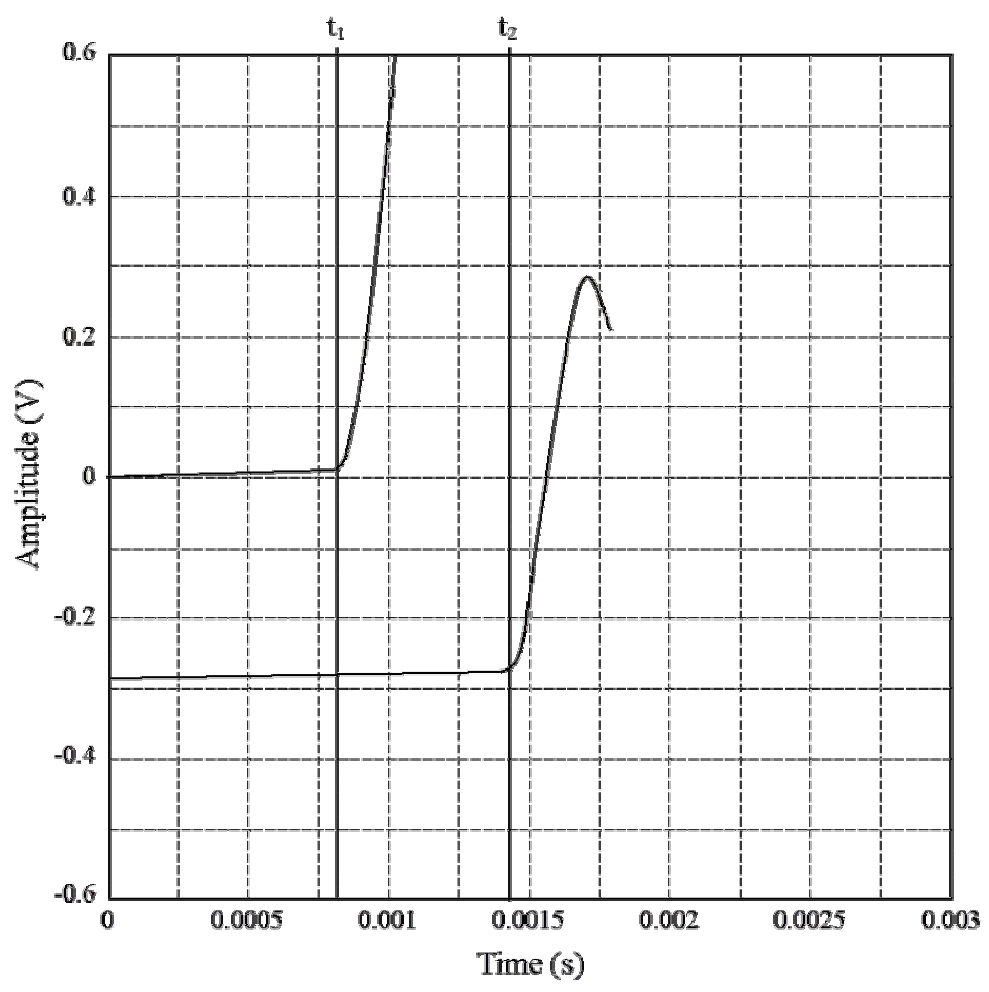

The ultimate goal of Wang's study was to find a nondestructive measurement technique to assess the relative quality of standing trees (Wang 2001a). Realizing that stress wave propagation in a highly anisotropic, heterogeneous material such as wood is very complex, he felt estimates of a material property of a tree may be made by a global treatment of stress wave propagation in the tree. Although the reported values from Wang's study are global estimates, he found that they can provide an indication of quality that can be used to assess the relative value of the wood in a standing tree.

Wang (1999) is notable for several reasons: 
1. The study showed strong correlative relationships between in situ tree measurements and the properties of clear wood in the trees.

2. Based on his results, a commercially available tool was developed for assessing the mechanical properties of standing trees. 


\section{Chapter 3 Objectives}

The objective of this study was to build upon the positive results of Wang (1999).

Specific objectives were to:

1. Examine the use of stress-wave NDE to assess the quality of wood in standing red pine and ponderosa pine timber.

2. Evaluate the use of the newly developed tool to assess the quality of standing red pine and ponderosa pine timber. 


\section{Chapter 4 Methods}

\subsection{Tree Selection}

A diagram that illustrates key components of this study is shown in Figure 3. Sixty red pine (Pinus resinosa) trees and 115 ponderosa pine (Pinus ponderosa) trees were selected for in-field testing.

Figure 3. Nondestructive testing of trees followed by nondestructive testing of logs.

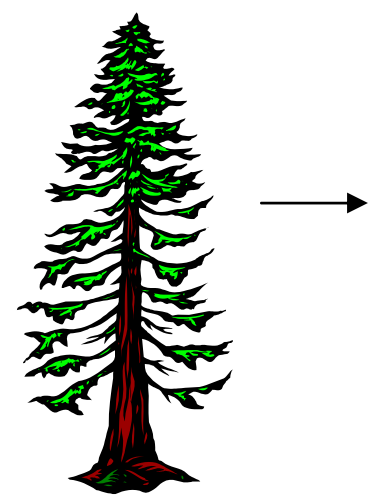

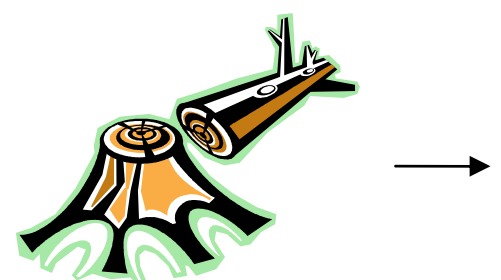

Harvest trees

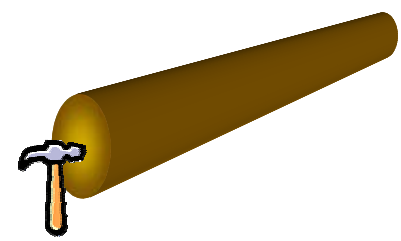

Stress wave analysis on logs

Nondestructive evaluation on standing trees

The red pine trees were on a site located in south central Wisconsin. A photograph of the stand is shown in Figure 4. These trees were planted in a sandy loam soil in the mid 1950's using a 6' by 6' spacing. This stand was first thinned in the 1970's with the removal of every other row of trees. In 1992, the stand had a basal area of $148 \mathrm{ft}^{2} /$ acre, with an average DBH of 8.7 inches. At that time, trees were selectively harvested which resulted in residual basal area of $105 \mathrm{ft}^{2} /$ acre. Before making measurements on the trees, we conducted an initial visual assessment of the site. We noted that the site had 55 rows and 40 columns of trees. Using a random number generator, we randomly selected 60 trees for testing and harvest. DBH for the 60 trees ranged from 7 to 14 inches. 
Figure 4. Wisconsin red pine trees (Arena, WI).

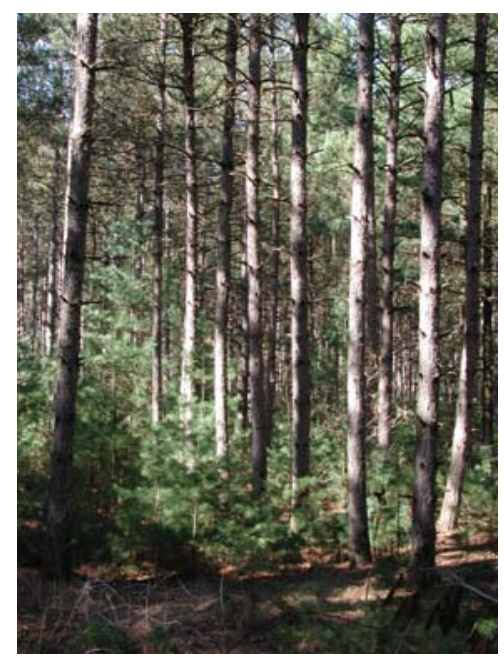

A photograph of several ponderosa pine trees used in this study is shown in Figure 5.

There trees were located in a stand on the Boise National Forest located approximately six miles southwest of Idaho City, Idaho. The soil type for the stand was sandy loam from decomposed granite. The stand was planted in 1961 with a 6' by 6' spacing and was thinned to a $10^{\prime}$ by $10^{\prime}$ spacing in 1977 . One hundred and fifteen test trees were randomly selected from a two-acre plot for analysis based on diameter classes of 6 to 15 inch DBH (Table 5) Of the one hundred and fifteen test trees, twenty five were tested with the commercial tree testing tool due to time constraints and equipment availability.

Figure 5. Idaho ponderosa pine trees (Boise National Forest, ID).

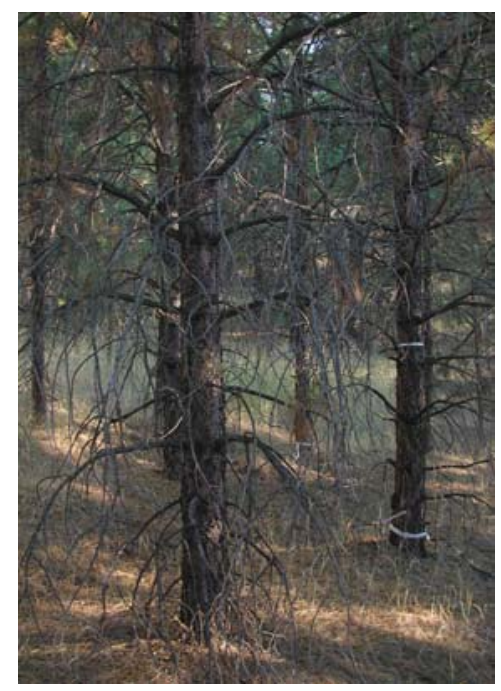


Table 5. Diameter classes of ponderosa pine trees.

\begin{tabular}{ll}
\hline Diameter class (in.) & Number of trees tested \\
\hline $6-8$ & 43 \\
$8-10$ & 31 \\
$10-12$ & 25 \\
$12-15$ & 16 \\
\hline
\end{tabular}

\subsection{Experimental Techniques}

\subsubsection{Laboratory-based equipment}

The experimental setup developed by Wang et al. (2000b) is shown in Figure 6.

The setup consisted of two Columbia

Model 3021 accelerometers, two 60-

penny spikes, and a Fluke Model

DM548810 Scopemeter. The two

spikes were embedded into the trunk of

a tree at angle of approximately $45^{\circ}$ to

the trunk's surface with a measured

span of 4 feet. Accelerometers were

then mounted on the spikes using

specially designed clamps, as shown in

Figure 7. A stress wave was introduced

into the tree so as to flow in the

longitudinal direction by impacting the
Figure 6. Laboratory-based experimental setup using two probes inserted $45^{\circ}$ into tree stem and two accelerometers wired to an oscilloscope.

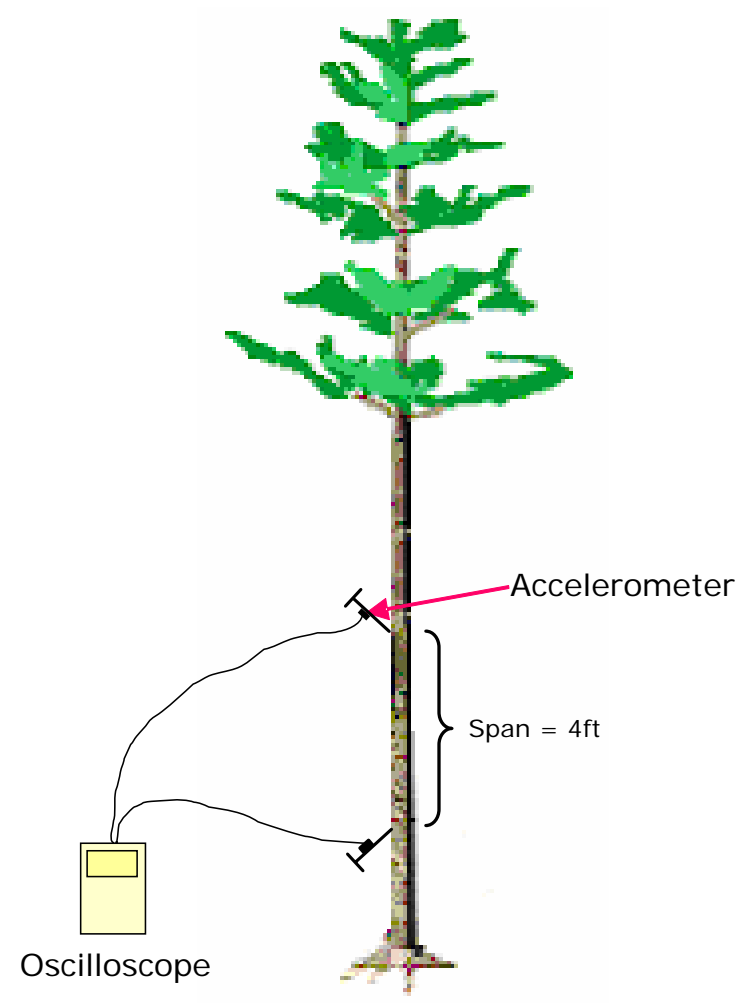

lower spike with a hammer. The resulting signals were received by the start and stop accelerometers and recorded on the oscilloscope (Figure 8). The stress wave 
transmission time was determined by locating the two leading edges of the waveforms.

Figure 7. Accelerometer clamped onto a spike embedded into stem at $45^{\circ}$ to grain.

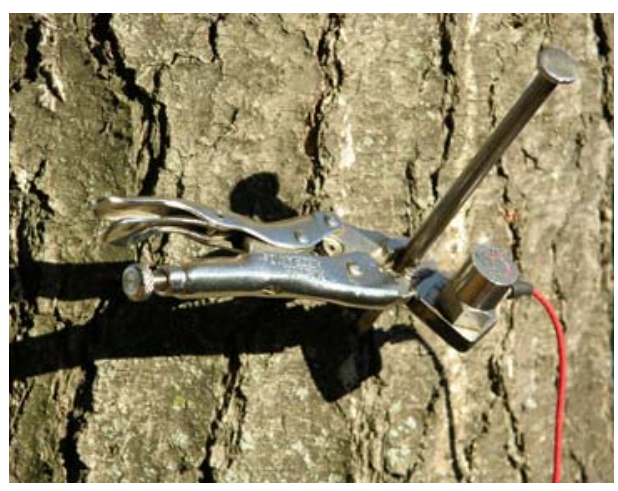

Figure 8. Start and stop signals from accelerometers shown on oscilloscope.

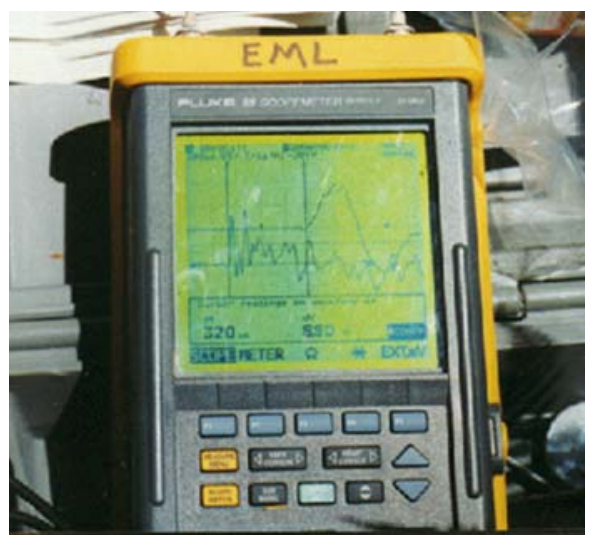

\subsubsection{Commercial tree assessment tool}

Based on the positive results of Wang (1999), fibre-gen (Auckland, New Zealand) undertook an intensive effort to develop a tree assessment tool for field use. They based their design on Wang's (1999) laboratory technique. The resulting tool (Figure 9) consists of transmitting and receiving probes coupled to a PDA via wireless technology. A built-in laser in the receiving probe is aimed at a target on the transmitting probe for alignment purposes. A pulse echo ultrasound system is used to determine the distance between the probes. To determine the quality of the wood, sound waves are induced into the stem by impacting the transmitting probe with a hammer. Stress-wave speed is automatically calculated and shown on the built-in LCD screen on the receiving probe. Infrared data transmission is used to send the information to the PDA. 
Figure 9. Setup of commercial tree assessment tool includes specially-designed probes and a PDA for wireless data collection.

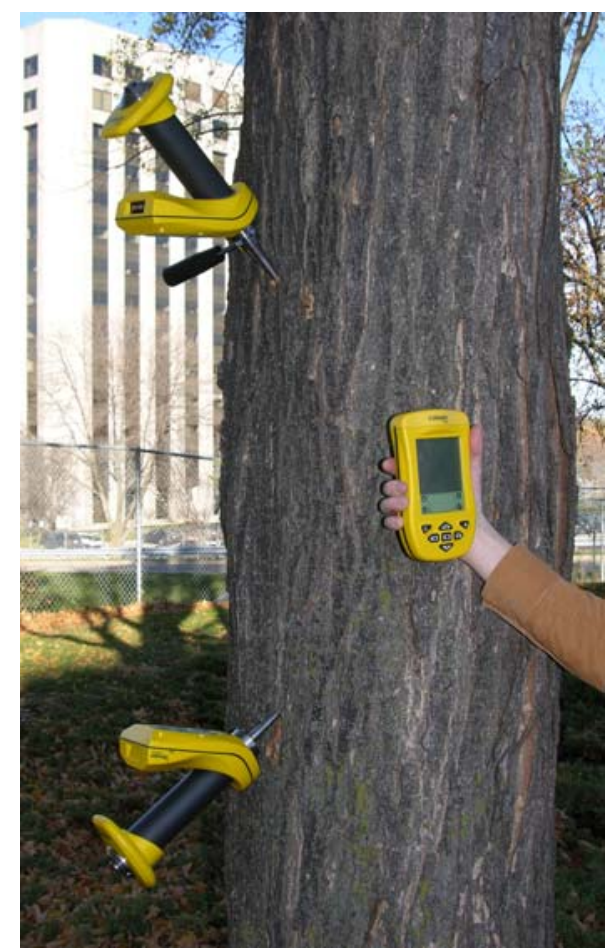

\subsection{Harvesting of trees}

All selected ponderosa pine trees were harvested and sixty-nine $81 / 2-\mathrm{ft}$ ponderosa pine butt logs were shipped to the USDA Forest Products Laboratory (FPL) for further analysis. Not all logs were shipped due to transportation constraints. Table 6 shows a summary, by diameter class, of the logs shipped to FPL.

Table 6. Diameter classes of ponderosa pine logs sent to the USDA Forest Products Laboratory (Madison, WI) for further testing.

\begin{tabular}{ll}
\hline Diameter class (in.) & Number of logs sent to FPL \\
\hline $6-8$ & 24 \\
$8-10$ & 22 \\
$10-12$ & 14 \\
$12-15$ & 9 \\
\hline
\end{tabular}

Thirty red pine trees were harvested and bucked into 15-ft logs. These logs were then shipped to the FPL for further analysis. 


\subsection{Laboratory evaluation of logs}

Speed of sound transmission for each $\log$ was determined using a resonance stress wave technique (Director HM 200, fibre-gen, Auckland, New Zealand). This technique involves impacting one end of the log, and then monitoring the movement of the wave within the log. A schematic diagram that illustrates wave motion in the logs is shown in Figure 10. Upon impact a compression wave is generated and immediately begins moving down the log. As particles at the leading edge of the wave become excited, particles at the trailing edge come to rest. After traveling the length of the log, the wave impinges on the free end of the log and is reflected as a tensile wave traveling back down the log. Photographs illustrating the equipment used to measure log speed of sound values are shown in Figures 11 and 12.

Figure 10. Travel of compression wave along log. The forward-moving wave impinges on the free end of the log, is reflected as a tensile wave, and begins to travel back down the log (Pellerin and Ross 2002).
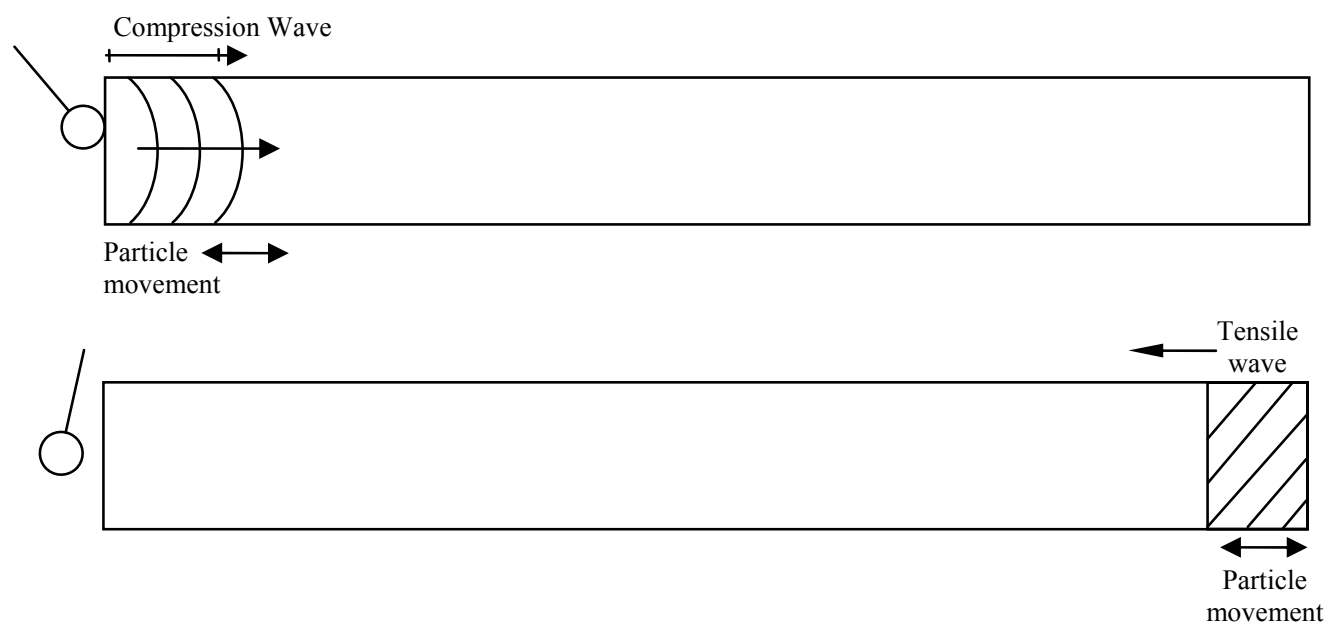
Figure 11. Log acoustic properties measured with a resonance stress wave technique using the Director HM200.

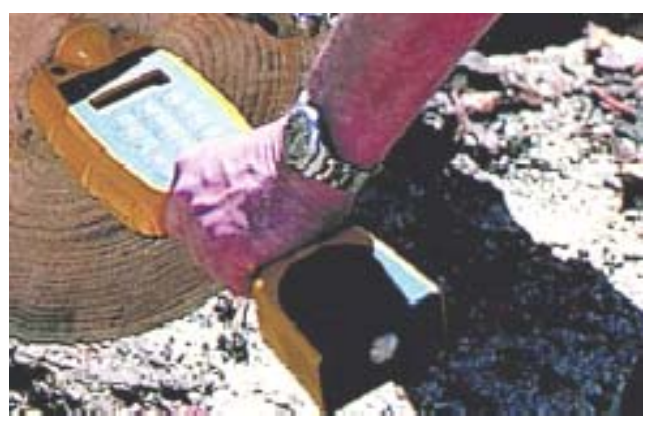

Figure 12. Determining acoustic properties of red pine logs with Director HM200 (fibre-gen, Auckland, New Zealand).

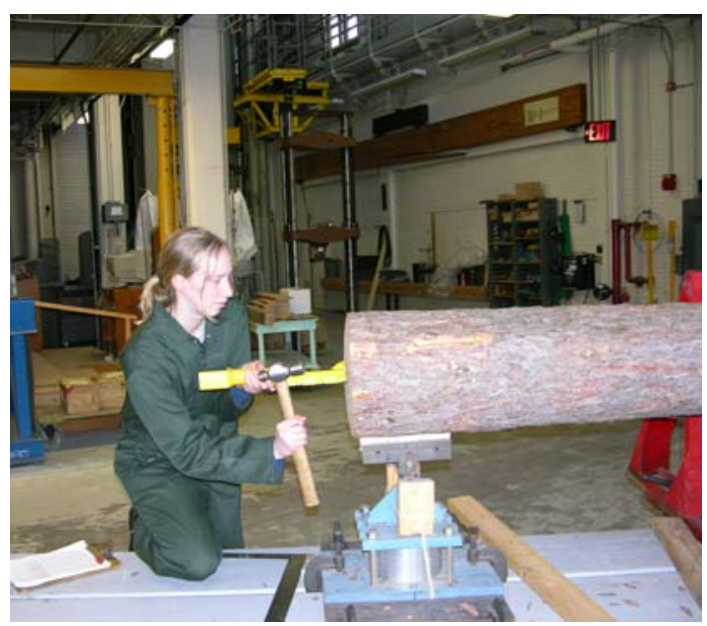

\subsection{Analysis of data}

Mathematical correlation models between measurements made with both standing tree measurement techniques were of the following form:

$y=a+b x$

where:

$y=$ stress wave speed value for standing tree observed using laboratory equipment (ft/s),

$\mathrm{x}=$ stress wave speed value for standing tree observed using commercial tree assessment tool (ft/s),

$\mathrm{a}=\mathrm{y}$-intercept of regression line $(\mathrm{ft} / \mathrm{s})$, and

$b=$ regression coefficient, or slope of regression line. 
Linear regression analysis of the data was used to determine values for a and b.

Similarly, the mathematical regression model between standing tree and log stress wave speed values were of the following form:

$$
y=a+b x
$$

where:

$\mathrm{y}=$ stress wave speed value for standing tree $(\mathrm{ft} / \mathrm{s})$,

$\mathrm{x}=$ stress wave speed value for $\log (\mathrm{ft} / \mathrm{s})$,

$\mathrm{a}=\mathrm{y}$-intercept of regression line $(\mathrm{ft} / \mathrm{s})$, and

$b=$ regression coefficient, or slope of regression line. 


\section{Chapter 5 Results and Discussion}

\subsection{Statistical relationship between laboratory-based method and commercial tree}

assessment tool (red pine and ponderosa pine)

The relationship of stress-wave speed in red pine and ponderosa pine trees using measurements from the laboratory-based method and commercial tree assessment tool are represented in Table 7 and Figure 13. Linear correlation analysis was performed, resulting in a regression coefficient of 0.97 , indicating a $98 \%$ similarity in values of the laboratory method and commercial tree assessment tool. The y-intercept represents the stress wave speed of the laboratory method when the commercial tool has a value of zero, indicating the commercial tool gave stress wave speeds $670 \mathrm{ft} / \mathrm{s}$ lower than the laboratory method. Standard error for the data set is $636 \mathrm{ft} / \mathrm{s}$, while the correlation coefficient is 0.97. Linear correlation analysis performed separately on red pine and ponderosa pine data gave regression coefficients of 0.72 and 0.70 , and y-intercepts of $3291 \mathrm{ft} / \mathrm{s}$ and 2141 $\mathrm{ft} / \mathrm{s}$, respectively. Y-intercept values indicate the commercial tool provides stress wave speed values lower than the laboratory method, and according to the regression coefficients, the difference is about $30 \%$. Correlation coefficients and standard error values were 0.93 and $224 \mathrm{ft} / \mathrm{s}$ for red pine and 0.83 and $758 \mathrm{ft} / \mathrm{s}$ for ponderosa pine. Overall the commercial tool gave stress wave speed values lower than the laboratory method, and there was more variability in ponderosa pine data than red pine data. These variations may be attributed to the following factors: 1) The ponderosa pine trees were tested with the commercial tree assessment tool in its early stages of development. As the tool was refined and optimized, stronger relationships between the commercial tool and 
the laboratory technique data were found, as were present in the red pine study. 2) For the laboratory-based method, the placement of accelerometers on the spikes could have affected the calculated stress wave speed. The spikes are inserted into the tree four feet apart, where the span measurement is taken at the point where the spike enters the tree. The actual span of the stress wave measurement is the distance between accelerometers, not the distance between spikes. The accelerometers can be clamped anywhere along the length of the spike, causing a discrepancy between the recorded span (the distance between spikes) and the actual span (the distance between accelerometers), thus affecting the calculation of stress wave speed. The commercial tree assessment tool has probes with built-in accelerometers, so the location of the accelerometers on the spike are consistent. Also, a measuring tape is used to measure the span for the laboratory method, while the commercial tool measures the distance between accelerometers using ultrasound, resulting in a more accurate and consistent measurement.

Table 7. Statistical relationship of stress wave speed in red pine and ponderosa pine trees using the commercial tree assessment tool (Y) and laboratory-based technique (X).

\begin{tabular}{llllll}
\hline & & \multicolumn{4}{c}{ Linear Regression Model: $\mathrm{y}=\mathrm{a}+\mathrm{bx}$} \\
\cline { 3 - 6 } Series & $\mathrm{n}$ & $\mathrm{a}$ & $\mathrm{b}$ & $\mathrm{r}$ & $\mathrm{S}_{\mathrm{yx}}$ \\
\hline Red pine & 60 & 3291 & 0.72 & 0.93 & 224 \\
Ponderosa pine & 25 & 2141 & 0.70 & 0.83 & 758 \\
\hline
\end{tabular}


Figure 13. Relationship of stress wave speed in red pine and ponderosa pine trees using the laboratory stress wave method and the commercial tool.

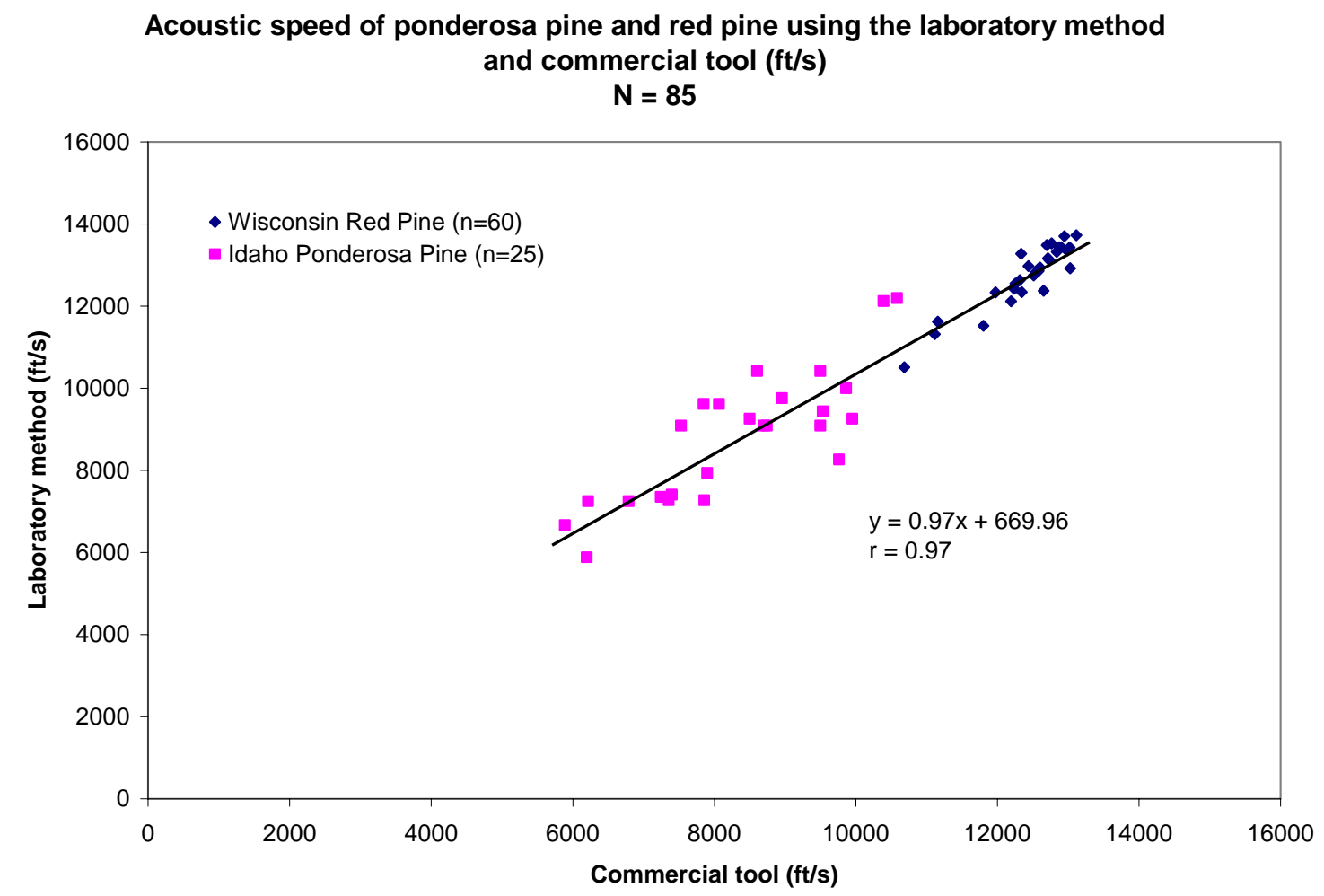

\subsection{Relationship between standing tree and log evaluation (red pine and ponderosa}

pine)

Linear regression analysis was used to analyze the relationship between the stress-wave speed of trees and logs using two different nondestructive evaluation tools (Table 8 and Figure 14). Stress wave speed of trees found using the commercial tree assessment tool were compared to the stress wave speed of logs using the resonance stress-wave tool. Linear regression analysis was performed, resulting in a correlation coefficient of 0.96 and standard error of $604 \mathrm{ft} / \mathrm{s}$ for the data set. The regression coefficient is 0.89 and the $y-$ intercept is $779 \mathrm{ft} / \mathrm{s}$, indicating the stress wave speed values of trees are about $10 \%$ higher than those of the logs. These data agree with prior studies where stress wave values from 
logs were lower than those from trees (Wang et al. 1999, 2000b, 2001b). The deviation of tree velocity from log velocity may be attributed to these factors: 1) Different wave propagation mechanisms exist for the two different acoustic measurement techniques. According to Wang (2005), stress waves are induced into a tree by indirect impact (through a probe) on the side surface of the trunk, resulting in a dilatational wave through the wood. For logs, stress waves are introduced by a direct impact on the end of the log, resulting in a one dimensional longitudinal wave traveling along the longitudinal axis of the log. Because dilatational waves travel faster than plane waves in materials (Wang 2005), it is plausible that stress waves will travel faster in trees. 2) Stress wave measurements on trees are time-of-flight measurements, where only the first pass of the sound wave is measured. The resonance stress wave technique measures over 150-200 passes of the log length, providing an average of many individual measurements. Principles of statistics state that variation is dependent upon sample size; therefore, there may be more variation in standing tree data. 3) Different measurement techniques may result in varying spans for the two acoustic measurement methods. The probes of the commercially available tree assessment tool must pass through the bark of the tree and into the cambium to effectively emit stress wave signals through the tree. To measure the stress wave speed in logs, the cross-section of the log is impacted directly without having to go through bark and without using a spike to transmit the wave. On the tree measurements, the length between the accelerometer, where the stress wave is sensed, and the cambium of the tree, where the stress wave begins going through wood, may be large enough to affect the stress wave speed of the wood in the tree; whereas for the log measurements, the accelerometer is placed directly on the face of the log, reducing the chance for error in span measurements. 4) The anisotropy of wood may contribute to 
differences between tree and $\log$ stress wave values. When trees are analyzed, the stress wave enters the wood perpendicularly from the side and has to travel through growth rings and layers of xylem before it attains a longitudinal-traveling path. Once it begins traveling along the stem of the tree, it passes through the wood cells more easily because they are oriented in a longitudinal direction.

Knowing that the $10 \%$ difference in stress wave speed between trees and logs may be due to wave properties, accelerometer placement, and wood anisotropy, it is concluded that tree stress wave speeds measured with the commercial tree assessment tool strongly correlate with $\log$ stress wave speeds. These results suggest that the commercial tree assessment tool gives stress-wave data similar to that of the laboratory-based measurement method, indicating its usefulness as a tool for predicting timber quality.

Table 8. Relationship of stress wave speed in red pine and ponderosa pine trees using the commercial tree assessment tool $(\mathrm{Y})$ and logs using resonance-based stress wave technique (X).

\begin{tabular}{llllll}
\hline & & \multicolumn{4}{c}{ Linear Regression Model: $\mathrm{y}=\mathrm{a}+\mathrm{bx}$} \\
\cline { 3 - 6 } Species & $\mathrm{n}$ & $\mathrm{a}$ & $\mathrm{b}$ & $\mathrm{r}$ & $\mathrm{S}_{\mathrm{yx}}$ \\
\hline Red pine & 30 & 6129 & 0.61 & 0.85 & 311 \\
Ponderosa pine & 25 & 2146 & 0.52 & 0.80 & 538 \\
\hline
\end{tabular}


Figure 14. Relationship of stress wave speed of trees and logs using data from the commercial tool and the $\log$ resonance stress wave technique.

Acoustic speed of ponderosa pine and red pine using resonance stress wave technique and commercial tree testing tool (ft/s)

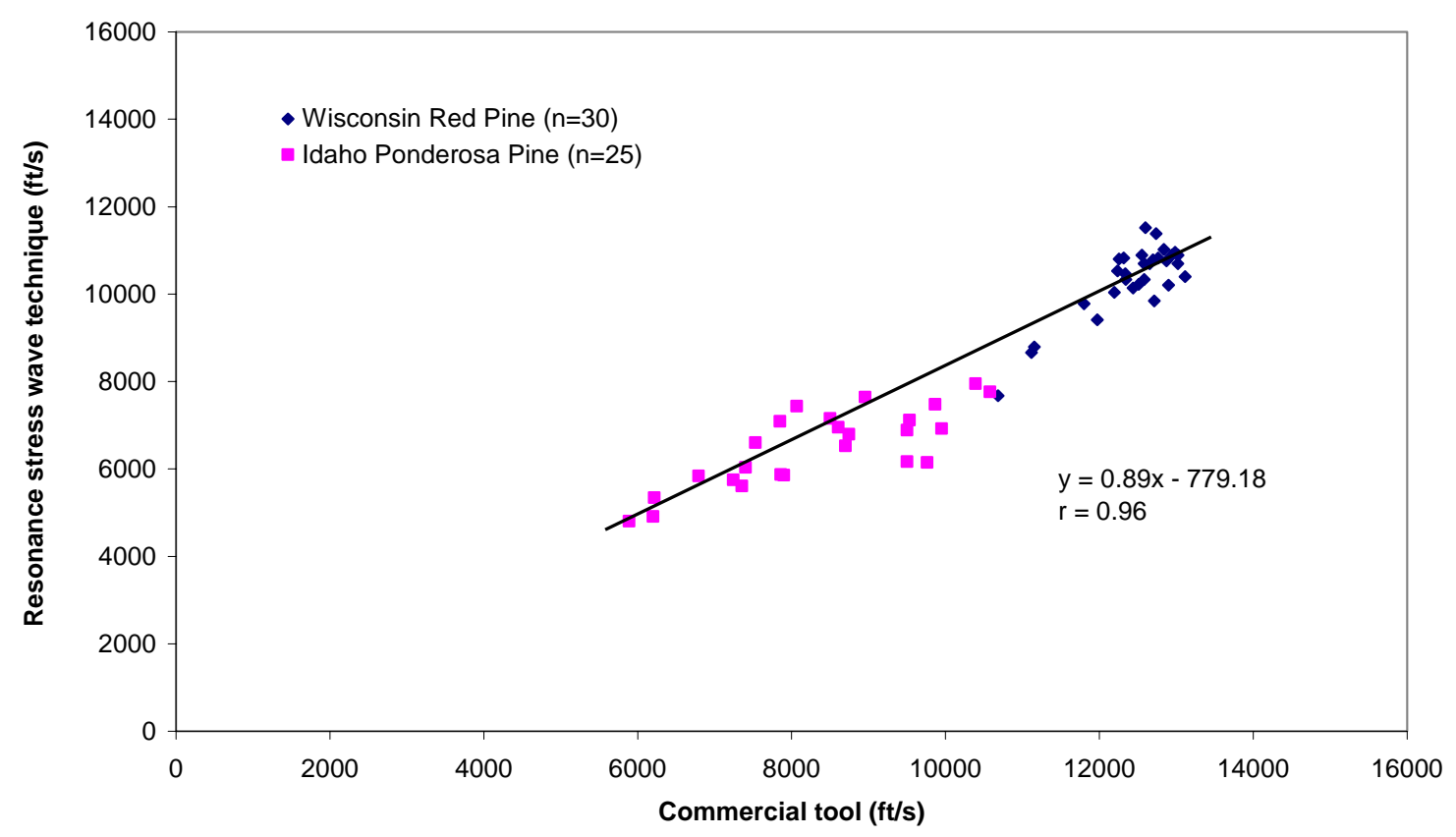

\subsection{Statistical relationship of trees and logs (worldwide data set)}

To this date, numerous studies using the laboratory-based method and commercial tree assessment tool on stress-wave analysis of standing trees have been conducted on trees from ecosystems around the world. Trees from different environments with varying types of soil, moisture, and sunlight will produce wood with different specific gravities, structures, and homogeneity. Stress-wave analysis is applicable for all types of wood and is largely species- and density-independent. Table 9 , Figure 15 , and Table 10 summarize the results of all standing timber studies available to the author to date. The data found with the commercial tree assessment tool fit on the same regression line as the data found with the laboratory-based method, confirming the predictability of wood quality using the 
commercial tree assessment tool. Regression information is shown in Table 9 with a correlation coefficient of 0.95 and a regression coefficient of 0.71 , indicating an average difference between tree and log values of almost $30 \%$. The y-intercept of $1354 \mathrm{ft} / \mathrm{s}$ indicates the values of logs being higher than those of trees.

Table 9. Relationships between stress-wave speed of trees and logs using the commercial tree assessment tool and laboratory-based method for entire data population.

\begin{tabular}{lllllll}
\hline & & \multicolumn{5}{c}{ Linear Regression Model: $\mathrm{y}=\mathrm{a}+\mathrm{bx}$} \\
\cline { 3 - 7 } & & $\begin{array}{l}\text { Y: Equipment used } \\
\text { for stress-wave } \\
\text { Series }\end{array}$ & $\mathrm{n}$ & $\begin{array}{l}\text { X: Stress-wave speed of logs using } \\
\text { resonance stress-wave technique } \\
(\mathrm{ft} / \mathrm{s})\end{array}$ \\
\hline All data & 1084 & $\begin{array}{l}\text { Commercial tool and } \\
\text { laboratory method }\end{array}$ & 1354 & 0.71 & 0.95 & 768 \\
\hline
\end{tabular}

Figure 15. Data bank of stress-wave analysis on logs and standing trees using the commercial tree assessment tool and laboratory-based method.

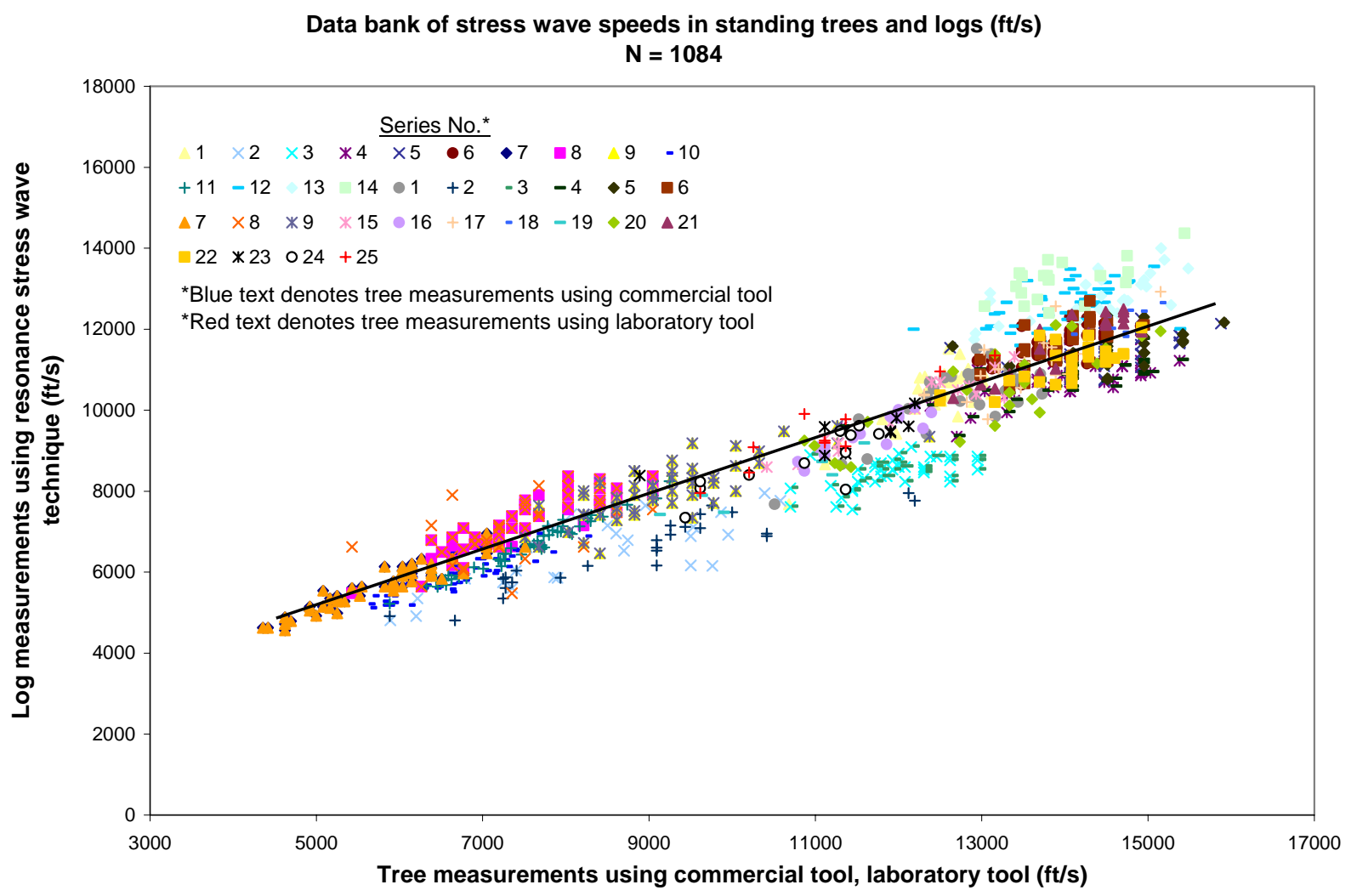


Statistical data for each individual series are shown in Table 10 with correlation coefficient values ranging from 0.35 to 0.98 , standard errors from 117 to $592 \mathrm{ft} / \mathrm{s}$, and regression coefficient values ranging from 0.24 to 0.99 . Some data series have lower correlation coefficients, higher standard errors or smaller regression line slopes for a number of reasons: 1) The commercial tree assessment tool has undergone continual improvement since the first version was created in 2004. Some of the data in this chart were measured with the prototype version of the tool, where problems were found and improvements were made. As the tool was refined, the relationship between tree and log data became stronger. 2) Some data sets have very few data points, as low as six samples. Principles of statistics state that variation is dependent upon sample size, so when the sample size is low, there will be greater variation. Sometimes it is not economically viable for a researcher to use the appropriate amount of samples in a study. For example, the Sitka spruces measured in Alaska were in a temperate rainforest littered with fallen logs and rotten trees; it was a challenge to fell an appropriate number of trees in a limited amount of time. 3) User error can also contribute to data variation. The studies completed in New Zealand, for example, were conducted by different individuals than those in the United States. Each person taking measurements could interpret the data in different ways which could lead to data further variation.

Table 10. Data bank of relationships between stress-wave speed of trees and logs using the commercial tree assessment tool, laboratory-based method, and resonance stress wave technique.

\begin{tabular}{|c|c|c|c|c|c|c|c|c|}
\hline \multirow{3}{*}{$\begin{array}{l}\text { Series } \\
\text { No. }\end{array}$} & \multirow[b]{3}{*}{ Species } & \multirow[b]{3}{*}{ Location } & \multirow[b]{3}{*}{$n$} & \multicolumn{5}{|c|}{ Linear Regression Model: $y=a+b x$} \\
\hline & & & & \multirow{2}{*}{$\begin{array}{l}\text { Y: Equipment } \\
\text { used for } \\
\text { stress-wave } \\
\text { speed of trees } \\
(\mathrm{ft} / \mathrm{s})^{\mathrm{a}}\end{array}$} & \multicolumn{4}{|c|}{$\begin{array}{l}\text { X: Stress-wave speed of logs using } \\
\text { resonance stress-wave technique }(\mathrm{ft} / \mathrm{s})\end{array}$} \\
\hline & & & & & $\mathrm{a}$ & $\mathrm{b}$ & $\mathrm{r}$ & $\mathrm{S}_{\mathrm{yx}}$ \\
\hline \multirow[t]{2}{*}{1} & Red pine & Wisconsin & 30 & $\begin{array}{l}\text { Commercial } \\
\text { tool }\end{array}$ & 6129 & 0.61 & 0.85 & 311 \\
\hline & & & & $\begin{array}{l}\text { Laboratory } \\
\text { method }\end{array}$ & -428 & 0.84 & 0.78 & 524 \\
\hline
\end{tabular}




\begin{tabular}{|c|c|c|c|c|c|c|c|c|}
\hline \multirow{2}{*}{$\begin{array}{l}\text { Series } \\
\text { No. }\end{array}$} & \multirow[b]{2}{*}{ Species } & \multirow[b]{2}{*}{ Location } & \multirow[b]{2}{*}{$\mathrm{n}$} & \multirow{2}{*}{$\begin{array}{l}\text { Y: Equipment } \\
\text { used for } \\
\text { stress-wave } \\
\text { speed of trees } \\
(\mathrm{ft} / \mathrm{s})^{\mathrm{a}}\end{array}$} & \multicolumn{4}{|c|}{$\begin{array}{l}\mathrm{X} \text { : Stress-wave speed of logs using } \\
\text { resonance stress-wave technique }(\mathrm{ft} / \mathrm{s})\end{array}$} \\
\hline & & & & & $\mathrm{a}$ & $\mathrm{b}$ & $\mathrm{r}$ & $\mathrm{S}_{\mathrm{yx}}$ \\
\hline \multirow[t]{2}{*}{2} & Ponderosa pine & Idaho & 25 & $\begin{array}{l}\text { Commercial } \\
\text { tool }\end{array}$ & 2146 & 0.52 & 0.80 & 538 \\
\hline & & & & $\begin{array}{l}\text { Laboratory } \\
\text { method }\end{array}$ & 1997 & 0.51 & 0.92 & 342 \\
\hline \multirow[t]{2}{*}{3} & Radiata pine 1 & Australia & 39 & $\begin{array}{l}\text { Commercial } \\
\text { tool }\end{array}$ & 3871 & 0.38 & 0.58 & 312 \\
\hline & & & & $\begin{array}{l}\text { Laboratory } \\
\text { method }\end{array}$ & 3881 & 0.38 & 0.58 & 313 \\
\hline \multirow[t]{2}{*}{4} & Radiata pine 2 & Australia & 39 & $\begin{array}{l}\text { Commercial } \\
\text { tool }\end{array}$ & 4154 & 0.47 & 0.71 & 395 \\
\hline & & & & $\mathrm{L}$ & 4165 & 0.47 & 0.71 & 396 \\
\hline \multirow[t]{2}{*}{5} & Radiata pine 3 & Australia & 39 & $\mathrm{C}$ & 8016 & 0.24 & 0.34 & 395 \\
\hline & & & & $\mathrm{L}$ & 8036 & 0.24 & 0.34 & 396 \\
\hline \multirow[t]{2}{*}{6} & Radiata pine 4 & Australia & 40 & $\mathrm{C}$ & 2905 & 0.62 & 0.61 & 388 \\
\hline & & & & $\mathrm{L}$ & 2913 & 0.62 & 0.61 & 389 \\
\hline \multirow[t]{2}{*}{7} & Radiata pine 5 & New Zealand & 50 & $\mathrm{C}$ & 1513 & 0.72 & 0.94 & 195 \\
\hline & & & & $\mathrm{L}$ & 1513 & 0.72 & 0.94 & 195 \\
\hline \multirow[t]{2}{*}{8} & Radiata pine 6 & New Zealand & 50 & $\mathrm{C}$ & 1415 & 0.77 & 0.87 & 342 \\
\hline & & & & $\mathrm{L}$ & 2710 & 0.60 & 0.69 & 525 \\
\hline \multirow[t]{2}{*}{9} & Radiata pine 7 & New Zealand & 50 & $\mathrm{C}$ & 2505 & 0.60 & 0.79 & 450 \\
\hline & & & & $\mathrm{L}$ & 2505 & 0.60 & 0.79 & 450 \\
\hline 10 & Radiata pine 8 & New Zealand & 50 & $\mathrm{C}$ & 44 & 0.87 & 0.98 & 116 \\
\hline 11 & Radiata pine 9 & New Zealand & 50 & $\mathrm{C}$ & 1311 & 0.69 & 0.90 & 217 \\
\hline 12 & Douglas fir A & Oregon & 45 & $\mathrm{C}$ & 6432 & 0.44 & 0.53 & 424 \\
\hline 13 & Douglas fir B & Oregon & 26 & $\mathrm{C}$ & 5666 & 0.50 & 0.68 & 419 \\
\hline 14 & Douglas fir C & Oregon & 20 & $\mathrm{C}$ & 6297 & 0.49 & 0.60 & 401 \\
\hline 15 & Sitka spruce & Alaska & 15 & $\mathrm{~L}$ & -457 & 0.86 & 0.94 & 298 \\
\hline 16 & $\begin{array}{l}\text { Western } \\
\text { hemlock }\end{array}$ & Alaska & 15 & $\mathrm{~L}$ & -172 & 0.82 & 0.89 & 235 \\
\hline 17 & Jack pine & Michigan & 18 & $\mathrm{~L}$ & -112 & 0.83 & 0.73 & 544 \\
\hline 18 & White birch & Michigan & 9 & $\mathrm{~L}$ & -724 & 0.88 & 0.88 & 247 \\
\hline 19 & Ponderosa pine & Oregon & 6 & $\mathrm{~L}$ & 1281 & 0.66 & 0.93 & 297 \\
\hline 20 & Slash pine A & Louisiana & 25 & $\mathrm{~L}$ & 422 & 0.76 & 0.85 & 591 \\
\hline 21 & Slash pine B & Louisiana & 24 & $\mathrm{~L}$ & -2300 & 0.99 & 0.87 & 345 \\
\hline 22 & Loblolly pine & Louisiana & 26 & $\mathrm{~L}$ & 2246 & 0.64 & 0.75 & 356 \\
\hline 23 & Red oak 1 & Missouri & 10 & $\mathrm{~L}$ & 4385 & 0.44 & 0.83 & 305 \\
\hline 24 & Red oak 2 & Missouri & 11 & $\mathrm{~L}$ & 1389 & 0.68 & 0.81 & 457 \\
\hline 25 & Red oak 3 & Missouri & 10 & $\mathrm{~L}$ & -785 & 0.92 & 0.94 & 382 \\
\hline
\end{tabular}

\footnotetext{
${ }^{\mathrm{a}} \mathrm{C}$, commercial tool; L, Laboratory method
} 


\section{Chapter 6 Conclusions}

Based on the results of this study, the following conclusions can be made:

1. The commercial tree assessment tool provides values similar to those of the laboratory-based method, demonstrating the commercial tree assessment tool's usefulness in determining the quality of standing timber.

2. Stress-wave measurement values from standing trees are similar to those from logs. Log values can be predicted from standing tree values indicating that standing timber quality can be accurately and reliably measured with stress-wave analysis.

3. The data collected in this study correlate with the worldwide standing timber data bank, confirming the usefulness of stress wave analysis across a range of tree species and ecosystems.

Based on these results, it is concluded that the commercial tree assessment tool is useful in determining the quality of standing trees. This research can be expanded on by using the commercial tree assessment tool to test trees from sites of different thinning and pruning regimes, using stress-wave analysis to establish forest quality and to help make future management decisions. 


\section{Chapter 7 Literature Cited}

Bertholf, L.D. 1965. Use of elementary stress wave theory for prediction of dynamic strain in wood. Bulletin 291. Pullman, WA: Washington State University, College of Engineering.

Brown, H.P., Panshin, A.J., Forsaith, C.C. 1952. Textbook of Wood Technology. McGraw-Hill. New York.

Bucur, V. 1985. Ultrasonic, hardness, and x-ray densitometric analysis of wood. Ultrasonics. 11: 269-275.

Chudnoff, M., Eslyn, W.E., McKeever, D.B. 1984. Decay in mine timbers: Part III, Species-independent stress grading. Forest Products Journal. 34(3): 43-50.

Fagan, G.B.; Bodig, J. 1985. Computer simulation as a nondestructive evaluation tool. In: Proceedings, $5^{\text {th }}$ nondestructive testing of wood symposium; 1985 September 9-11; Pullman, WA. Pullman, WA: Washington State University: 3-37.

Gerhards, C.C. 1975. Stress wave speed and MOE of Sweetgum ranging from $150 \%$ to 15\% MC. Forest Products Journal. 25(4): 51-57. 
Gerhards, C.C. 1981. Effect of cross grain on stress waves in lumber. Res. Pap. FPL-RP368. Madison, WI: U.S. Department of Agriculture, Forest Service, Forest Products Laboratory.

Gerhards, C.C. 1982. Effect of knots on stress waves in lumber. Res. Pap. FPL-RP-384. Madison, WI: U.S. Department of Agriculture, Forest Service, Forest Products Laboratory.

Green, D. W.; Ross, R. J. 1997. Linking log quality with product performance. In: Barbour, R.J. and Skog, K.E., ed. Role of Wood Production in Ecosystem Management. Gen. Tech. Rep. FPL-GTR-100. Madison, WI: U.S. Department of Agriculture, Forest Service, Forest Products Laboratory. p. 53-58.

Huang, C. 2000. Predicting lumber stiffness of standing trees. In: Divos, F., ed. Proceedings, 12th international symposium on nondestructive testing of wood; 2000 September 13-15; University of Western Hungary, Sopron. Sopron, Hungary: University of Western Hungary: 173-180.

Ikeda, K.; Arima, T. 2000. Quality evaluation of standing trees by a stress-wave propagation method and its application. II. Evaluation of sugi stands and application to production of sugi structural square sawn timber. Mokuzai Gakkaishi. 46(3): 189-196.

Ikeda, K.; Kino, N. 2000. Quality evaluation of standing trees by a stress-wave propagation method and its application. I. Seasonal changes of moisture contents of sugi 
standing trees and evaluation with stress-wave propagation velocity. Mokuzai Gakkaishi. 46(3): 181-188.

Ikeda, K.; Kanamori, F.; Arima, T. 2000a. Quality evaluation of standing trees by a stress-wave propagation method and its application. IV. Application to quality evaluation of hinoki (Chaemaecyparis obutusa) standing plus trees. Mokuzai Gakkaishi. 46(6): 602608.

Ikeda, K.; Oomori, S.; Arima, T. 2000b. Quality evaluation of standing trees by a stresswave propagation method and its application. III. Application to sugi (Cryptomeria japonica) standing plus trees. Mokuzai Gakkaishi. 46(6): 558-565.

James, W.L. 1961. Effect of temperature and moisture content on: internal friction and speed of sound in Douglas-fir. Forest Products Journal. 11(9): 383-390.

Jayne, B.A. 1959. Vibrational properties of wood as indices of quality. Forest Products Journal. 9(11): 413-416.

Johnson, D.J. 1989. Thinning red pine. Forestry Fact Sheet 08. Michigan State University Extension.

Kahaner, D., Moler, C., Nash, S. 1988. Numerical Methods and Software. Prentice Hall. Upper Saddle River, NJ. 
Kaiserlik, J.H., Pellerin, R.F. 1977. Stress wave attenuation as an indicator of lumber strength. Forest Products Journal. 27(6): 39-43.

Love, A.E.H. 1944. A Treatise on the Mathematical Theory of Elasticity. Dover Publications. New York.

Meyers, M.A. 1994. Dynamic behavior of materials. John Wiley \& Sons, Inc. New York.

Mishiro, A. 1995. Ultrasonic velocity in wood and its moisture content. I. Effects of moisture gradients on ultrasonic velocity in wood. Mokuzai Gakkaishi. 41(12): 10861092.

Mishiro, A. 1996. Ultrasonic velocity and moisture content in wood. II. Ultrasonic velocity and average moisture content in wood during desorption (1)-Moisture content below the fiber saturation point. Mokuzai Gakkaishi. 42(6): 612-617.

Nakamura, N. 1996. Measurement of the properties of standing trees with ultrasonics and mapping of the properties. University Forest Research Rep. 96. Tokyo, Japan: Faculty of Agriculture, The University of Tokyo: 125-135.

Nanami, N.; Nakamura, N.; Arima, T.; Okuma, M. 1992. Measuring the properties of standing trees with stress waves. I. The method of measurement and the propagation path of the waves. Mokuzai Gakkaishi. 38(8): 739-746. 
Nanami, N.; Nakamura, N.; Arima, T.; Okuma, M. 1993. Measuring the properties of standing trees with stress waves. III. Application of the method to standing trees for some forest stands. Mokuzai Gakkaishi. 39(8): 903-909.

Patton-Mallory, M.; DeGroot, R.C. 1989. Acousto-ultrasonics for evaluating decayedwood products. In: Proceedings, $2^{\text {nd }}$ Pacific timber engineering conference; 1989 August 28-29; Auckland, New Zealand.

Pellerin, R.F. 1965. A vibrational approach to nondestructive testing of structural lumber. Forest Products Journal. 15(3): 93-101.

Pellerin, R.F., DeGroot, R.C., Esenther, G.R. 1985. Nondestructive stress wave measurements of decay and termite attack in experimental wood units. In: Proceedings, $5^{\text {th }}$ nondestructive testing of wood symposium; 1985 September 9-11; Pullman, WA. Pullman, WA: Washington State University: 319-353.

Pellerin, R.F., Kaiserlik, J.H. 1975. Non-destructive testing of particleboard. IUFRO, Div. 5, Wood Engineering Group Meeting.

Pellerin, R.F.; Morschauser, C.R. 1974. Nondestructive testing of particleboard. In: Proceedings, 7th international particleboard symposium; 1973 March; Pullman, WA. Pullman, WA: Washington State University. 
Pellerin, R.F.; Ross, R.J. 2002. Nondestructive Evaluation of Wood (Pellerin, R.F.; Ross, R.J.). Forest Products Society, Madison, WI.

Ross, R.J. 1984. Stress wave speed and attenuation as predictors of the tensile and flexural properties of wood-based particle composites. Pullman, WA: Washington State University. Ph.D. dissertation.

Ross, R.J. 1985. Stress wave propagation in wood products. In: Proceedings, 5th Nondestructive testing of wood symposium; 1985 September 9911; Pullman, WA. Pullman, WA: Washington State University: 291-318.

Ross, R.J.; Pellerin, R.F. 1988. NDE of wood-based composites with longitudinal stress waves. Forest Products Journal. 38(5): 39-45.

Ross, R.J.; Pellerin, R.F. 1994. Nondestructive testing for assessing wood members in structures: a review. Gen. Tech. Rep. FPL-GTR-70. Madison, WI: U.S. Department of Agriculture, Forest Service, Forest Products Laboratory.

Ross, R.J.; Ward, J.C.; TenWolde, A. 1992. Identifying bacterially infected oak by stress wave nondestructive evaluation. Res. Pap. FPL-RP-502. Madison, WI: U.S. Department of Agriculture, Forest Service, Forest Products Laboratory.

Rutherford, P.S. 1987. Nondestructive stress wave measurement of incipient decay in Douglas fir. Pullman, WA: Washington State University. M.S. thesis. 
Rutherford, P.S.; Hoyle, R.J.; DeGroot, R.C.; Pellerin, R.F. 1987. Dynamic vs. static MOE in the transverse direction in wood. In: Proceedings, $6^{\text {th }}$ nondestructive testing of wood symposium; 1987 September 14-16; Pullman, WA. Pullman, WA: Washington State University: 67-80.

Schad, K.C.; Schmoldt, D.L.; Ross, R.J. 1996. Nondestructive methods for detecting defects in softwood logs. Res. Pap. FPL-RP-546. Madison, WI: U.S. Department of Agriculture, Forest Service, Forest Products Laboratory. 13 p.

Sharp, D.J. 1985. Nondestructive testing techniques for manufacturing LVL and predicting performance. In: Proceedings, 5th nondestructive testing of wood symposium; 1985 September 9-11; Pullman, WA. Pullman, WA: Washington State University: 99108

Verksalo, E.; Ross, R.J.; TenWolde, A.; Youngs, R.L. 1993. Properties related to drying defects in red oak wetwood. Res. Pap. FPL-RP-516. Madison, WI: U.S. Department of Agriculture, Forest Service, Forest Products Laboratory.

Vogt, J.J. 1985. Evaluation of the tensile and flexural properties and internal bond of medium density fiberboard using stress wave speed and attenuation. Pullman, WA: Washington State University. M.S. thesis. 
Vogt, J.J. 1986. Longitudinal stress waves as predictors of internal bond strength. In: Proceedings, $12^{\text {th }}$ international particleboard/composite materials symposium; 1986 March; Pullman, WA. Pullman, WA: Washington State University.

Wang, X. 1999. Stress wave-based nondestructive evaluation (NDE) methods for wood quality of standing trees. Houghton, MI: Michigan Technological University. PhD Dissertation.

Wang, X.; Ross, R.J., Carter, P. 2005. Acoustic evaluation of standing trees - recent research development. In: Proceedings, $14^{\text {th }}$ international symposium on nondestructive testing of wood; 2005 May; Hannover, Germany. Eberswalde, Germany: University of Applied Sciences.

Wang, X.; Ross, R.J.; Erickson, J.R. [et al.] 2000a. Nondestructive evaluation of trees. Experimental Techniques. 24(6): 27-29.

Wang, X. 2001a. Response to "Comments on Nondestructive Evaluation of Trees" (Letter to Editor). Experimental Techniques. 25(2): 10.

Wang, X.; Ross, R.J.; Mattson, J.A. [et al.]. 2001b. Strength and stiffness assessment of standing trees using a nondestructive stress wave technique. Res. Pap. FP-RP-600. Madison, WI: U.S. Department of Agriculture, Forest Service, Forest Products Laboratory. $12 \mathrm{p}$. 
Wang, X.; Ross, R.J.; McClellan, M. [et al.]. 2000b. Strength and stiffness assessment of standing trees using a nondestructive stress wave technique. Res. Pap. FPL-RP-585.

Madison, WI: U.S. Department of Agriculture, Forest Service, Forest Products

Laboratory. 9 p.

Wu, S.Y.; Gorman, T.G., Wagner, F.G. 2000. Effect of slope aspect and scanning intensity on the correlation between stress-wave speeds in Douglas-fir trees and lumber MOE. Presented at the 54th annual meeting of the Forest Products Society; 2000 June 18121; South Lake Tahoe, Nevada. 


\section{Appendix}

Appendix A. Supply list for testing standing trees ................................................

Appendix B. Typical data sheet for standing tree measurements .................................

Appendix C. Typical data sheet for stress wave log measurements ...........................4

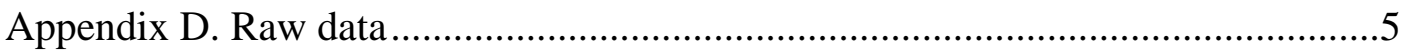

Red pine, Wisconsin..............................................................................

Ponderosa pine, Idaho .......................................................................

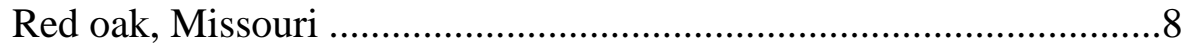

Radiata pine, Australia .....................................................................10

Radiata pine, New Zealand .................................................................12

Douglas fir, New Zealand; Slash pine, Louisiana .................................14

Sitka spruce, western hemlock, Alaska; Jack pine,

white birch; Michigan; ponderosa pine, Oregon;

Loblolly pine, Louisiana ……………………………........................15 
Appendix A. Supply list for testing standing trees

\begin{tabular}{|c|c|}
\hline \multicolumn{2}{|c|}{ Tree Testing Supply List } \\
\hline Director ST300 & Scopemeter \\
\hline The night before: & The night before: \\
\hline \multicolumn{2}{|l|}{$\square$ Charge PDA } \\
\hline$\square$ Arrange/gas vehicle & $\square$ Arrange/gas vehicle \\
\hline Bring: & Bring: \\
\hline$\square$ Voltmeter & $\square$ Voltmeter \\
\hline$\square$ Extra Batteries (AA) & $\square$ Extra Batteries (C) \\
\hline$\square$ Tape measure & $\square$ Tape measure \\
\hline$\square$ Director case & $\square$ scopemeter case \\
\hline$\square$ Wrenches & $\square$ Hammer \\
\hline$\square$ Director & $\square$ Scopemeter \\
\hline$\square$ Hammer & $\square$ Spikes \\
\hline$\square$ Wires for computer & $\square$ Extra wires \\
\hline$\square$ Thermometer & $\square$ Extra accelerometer \\
\hline$\square$ Orange vests & $\square$ Orange vests \\
\hline$\square$ Crayon for marking trees & $\square$ Crayon for marking trees \\
\hline$\square$ Spray paint & $\square$ Spray paint \\
\hline$\square$ Tree marking tape & $\square$ Tree marking tape \\
\hline$\square$ Pencils & $\square$ Pencils \\
\hline$\square$ Write-in-rain paper & $\square$ Write-in-rain paper \\
\hline
\end{tabular}


Appendix B. Data sheet for tree measurements

\begin{tabular}{|c|c|c|c|c|c|c|c|c|}
\hline \multirow{4}{*}{$\begin{array}{c}\text { Crew } \\
\text { Date } \\
\text { Tree } \\
\end{array}$} & \multirow{2}{*}{ 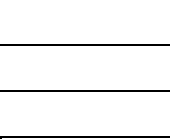 } & \multicolumn{2}{|c|}{$\begin{array}{r}\text { Location } \\
\text { Temperature }\end{array}$} & & & & & \multirow[b]{4}{*}{ Note } \\
\hline & & \multirow{2}{*}{\multicolumn{5}{|c|}{ Stress Wave Readings (usec) }} & \multirow{3}{*}{$\begin{array}{c}\text { Span } \\
(\mathrm{ft})\end{array}$} & \\
\hline & \multirow[b]{2}{*}{ DBH (in) } & & & & & & & \\
\hline & & 1 & 2 & 3 & Average & $\mathrm{ft} / \mu \mathrm{s}$ & & \\
\hline \multicolumn{9}{|l|}{1} \\
\hline \multicolumn{9}{|l|}{2} \\
\hline \multicolumn{9}{|l|}{3} \\
\hline \multicolumn{9}{|l|}{4} \\
\hline \multicolumn{9}{|l|}{5} \\
\hline \multicolumn{9}{|l|}{6} \\
\hline \multicolumn{9}{|l|}{7} \\
\hline \multicolumn{9}{|l|}{8} \\
\hline \multicolumn{9}{|l|}{9} \\
\hline \multicolumn{9}{|l|}{10} \\
\hline \multicolumn{9}{|l|}{11} \\
\hline \multicolumn{9}{|l|}{12} \\
\hline \multicolumn{9}{|l|}{13} \\
\hline \multicolumn{9}{|l|}{14} \\
\hline \multicolumn{9}{|l|}{15} \\
\hline \multicolumn{9}{|l|}{16} \\
\hline \multicolumn{9}{|l|}{17} \\
\hline \multicolumn{9}{|l|}{18} \\
\hline \multicolumn{9}{|l|}{19} \\
\hline \multicolumn{9}{|l|}{20} \\
\hline \multicolumn{9}{|l|}{21} \\
\hline \multicolumn{9}{|l|}{22} \\
\hline \multicolumn{9}{|l|}{23} \\
\hline 24 & & & & & & & & \\
\hline 25 & & & & & & & & \\
\hline 26 & & & & & & & & \\
\hline
\end{tabular}


Appendix C. Data sheet for stress wave log measurements.

Crew

Date

\begin{tabular}{|c|c|c|c|c|c|c|c|c|c|c|c|c|}
\hline \multirow{2}{*}{$\begin{array}{c}\text { Log } \\
\#\end{array}$} & \multicolumn{3}{|c|}{ Diameters (in) } & \multirow{2}{*}{$\begin{array}{l}\begin{array}{l}\text { Length } \\
\text { (ft) }\end{array} \\
\end{array}$} & \multirow{2}{*}{$\begin{array}{l}\text { Weight } \\
\text { (lb) }\end{array}$} & \multirow{2}{*}{$\begin{array}{l}\text { Density } \\
\left(\mathrm{b} / \mathrm{ft}^{3}\right)\end{array}$} & \multicolumn{4}{|c|}{ Stress Wave Times ( $\mu \mathrm{sec}$ ) } & \multirow{2}{*}{$\begin{array}{c}\text { Speed } \\
(\mathrm{ft} / \mathrm{s})\end{array}$} & \multirow[b]{2}{*}{ Note } \\
\hline & Top & Center & Butt & & & & 1 & 2 & 3 & Average & & \\
\hline 1 & & & & & & & & & & & & \\
\hline 2 & & & & & & & & & & & & \\
\hline 3 & & & & & & & & & & & & \\
\hline 4 & & & & & & & & & & & & \\
\hline 5 & & & & & & & & & & & & \\
\hline 6 & & & & & & & & & & & & \\
\hline 7 & & & & & & & & & & & & \\
\hline 8 & & & & & & & & & & & & \\
\hline 9 & & & & & & & & & & & & \\
\hline 10 & & & & & & & & & & & & \\
\hline 11 & & & & & & & & & & & & \\
\hline 12 & & & & & & & & & & & & \\
\hline 13 & & & & & & & & & & & & \\
\hline 14 & & & & & & & & & & & & \\
\hline 15 & & & & & & & & & & & & \\
\hline 16 & & & & & & & & & & & & \\
\hline 17 & & & & & & & & & & & & \\
\hline 18 & & & & & & & & & & & & \\
\hline 19 & & & & & & & & & & & & \\
\hline 20 & & & & & & & & & & & & \\
\hline 21 & & & & & & & & & & & & \\
\hline 22 & & & & & & & & & & & & \\
\hline 23 & & & & & & & & & & & & \\
\hline 24 & & & & & & & & & & & & \\
\hline
\end{tabular}


Red Pine; Arena, Wisconsin

\begin{tabular}{|c|c|c|c|c|c|c|c|c|c|c|c|c|c|c|c|c|}
\hline \multicolumn{17}{|c|}{ Standing tree assessment } \\
\hline \multirow[b]{3}{*}{ Tree } & \multirow[b]{3}{*}{ Row } & \multirow[b]{3}{*}{ Column } & \multirow{3}{*}{$\begin{array}{c}\mathrm{DBH} \\
\text { (in.) }\end{array}$} & \multicolumn{8}{|c|}{ Director ST300 (1/24/05) } & \multicolumn{5}{|c|}{ Scopemeter (1/24/05) } \\
\hline & & & & \multicolumn{2}{|c|}{ Distance } & \multirow[b]{2}{*}{1} & & & & & SWS & & & & SWS & SWS \\
\hline & & & & in. & $\mathrm{ft}$ & & 2 & 3 & average & SWS (ft/s) & $(\mu \mathrm{s} / \mathrm{ft})$ & 1 & 2 & 3 & $(\mathrm{ft} / \mathrm{s})$ & $(\mu \mathrm{s} / \mathrm{ft})$ \\
\hline 1 & 1 & 4 & 12.9 & 45.2 & 3.8 & 337 & 341 & 335 & 338 & 11155 & 89.65 & 324 & 324 & 324 & 11626 & 86.02 \\
\hline 2 & 1 & 9 & 12.9 & 50.8 & 4.2 & 327 & 325 & 332 & 328 & 12907 & 77.48 & 312 & 312 & 320 & 13453 & 74.33 \\
\hline 3 & 1 & 24 & 9.7 & 47.8 & 4.0 & 357 & 359 & 359 & 358 & 11116 & 89.96 & 352 & 352 & 352 & 11316 & 88.37 \\
\hline 4 & 1 & 35 & 9.0 & 48.5 & 4.0 & 347 & 347 & 342 & 345 & 11704 & 85.44 & 332 & 332 & 332 & 12174 & 82.14 \\
\hline 5 & 3 & 10 & 10.8 & 52.9 & 4.4 & 356 & 354 & 362 & 357 & 12337 & 81.06 & 332 & 332 & 332 & 13278 & 75.31 \\
\hline 6 & 3 & 34 & 10.5 & 48.5 & 4.0 & 329 & 329 & 333 & 330 & 12235 & 81.73 & 324 & 324 & 328 & 12423 & 80.49 \\
\hline 7 & 5 & 4 & 11.9 & 52.9 & 4.4 & 352 & 348 & 351 & 350 & 12583 & 79.47 & 344 & 344 & 336 & 12915 & 77.43 \\
\hline 8 & 5 & 14 & 10.1 & 52.1 & 4.3 & 329 & 327 & 325 & 327 & 13277 & 75.32 & 312 & 312 & 312 & 13916 & 71.86 \\
\hline 9 & 5 & 22 & 10.6 & 50.8 & 4.2 & 336 & 336 & 337 & 336 & 12587 & 79.45 & 332 & 328 & 328 & 12854 & 77.80 \\
\hline 10 & 5 & 28 & 11.6 & 46.3 & 3.9 & 296 & 300 & 303 & 300 & 12875 & 77.67 & 292 & 292 & 292 & 13213 & 75.68 \\
\hline 11 & 7 & 11 & 11.5 & 49.7 & 4.1 & 309 & 307 & 300 & 305 & 13564 & 73.72 & 304 & 304 & 304 & 13624 & 73.40 \\
\hline 12 & 8 & 24 & 11.0 & 50.1 & 4.2 & 335 & 331 & 328 & 331 & 12601 & 79.36 & 320 & 320 & 320 & 13047 & 76.65 \\
\hline 13 & 9 & 5 & 10.3 & 51.8 & 4.3 & 339 & 343 & 338 & 340 & 12696 & 78.76 & 320 & 320 & 320 & 13490 & 74.13 \\
\hline 14 & 9 & 16 & 11.2 & 50.1 & 4.2 & 339 & 338 & 338 & 338 & 12340 & 81.04 & 320 & 320 & 320 & 13047 & 76.65 \\
\hline 15 & 10 & 18 & 10.4 & 47.0 & 3.9 & 289 & 287 & 288 & 288 & 13600 & 73.53 & 280 & 280 & 280 & 13988 & 71.49 \\
\hline 16 & 11 & 30 & 9.4 & 52.6 & 4.4 & 334 & 341 & 339 & 338 & 12968 & 77.11 & 324 & 324 & 324 & 13529 & 73.92 \\
\hline 17 & 13 & 18 & 10.1 & 49.7 & 4.1 & 313 & 310 & 313 & 312 & 13275 & 75.33 & 308 & 304 & 304 & 13564 & 73.72 \\
\hline 18 & 15 & 15 & 12.1 & 46.9 & 3.9 & 310 & 311 & 316 & 312 & 12513 & 79.91 & 308 & 308 & 304 & 12745 & 78.46 \\
\hline 19 & 15 & 25 & 10.2 & 48.4 & 4.0 & 319 & 314 & 321 & 318 & 12683 & 78.84 & 308 & 308 & 308 & 13095 & 76.36 \\
\hline 20 & 16 & 8 & 9.2 & 51.1 & 4.3 & 327 & 332 & 328 & 329 & 12943 & 77.26 & 308 & 312 & 312 & 13707 & 72.95 \\
\hline 21 & 16 & 9 & 10.0 & 53.3 & 4.4 & 347 & 348 & 343 & 346 & 12837 & 77.90 & 332 & 332 & 336 & 13325 & 75.05 \\
\hline 22 & 16 & 12 & 11.3 & 47.5 & 4.0 & 318 & 317 & 316 & 317 & 12487 & 80.08 & 312 & 312 & 316 & 12633 & 79.16 \\
\hline 24 & 21 & 26 & 8.2 & 47.6 & 4.0 & 317 & 308 & 311 & 312 & 12714 & 78.66 & 304 & 300 & 300 & 13164 & 75.97 \\
\hline 25 & 21 & 31 & 9.0 & 50.0 & 4.2 & 336 & 341 & 343 & 340 & 12255 & 81.60 & 332 & 332 & 332 & 12550 & 79.68 \\
\hline 26 & 23 & 10 & 11.1 & 45.0 & 3.8 & 310 & 309 & 297 & 305 & 12282 & 81.42 & 288 & 292 & 292 & 12901 & 77.51 \\
\hline 27 & 24 & 10 & 10.3 & 47.8 & 4.0 & 339 & 329 & 342 & 337 & 11832 & 84.52 & 336 & 336 & 336 & 11855 & 84.35 \\
\hline 28 & 25 & 17 & 10.4 & 48.8 & 4.1 & 327 & 328 & 330 & 328 & 12386 & 80.74 & 316 & 316 & 320 & 12815 & 78.03 \\
\hline 29 & 26 & 31 & 9.8 & 51.2 & 4.3 & 335 & 335 & 335 & 335 & 12736 & 78.52 & 328 & 324 & 324 & 13115 & 76.25 \\
\hline 30 & 27 & 26 & 10.2 & 48.3 & 4.0 & 303 & 297 & 309 & 303 & 13284 & 75.28 & 296 & 296 & 296 & 13598 & 73.54 \\
\hline 31 & 29 & 11 & 10.1 & 49.3 & 4.1 & 309 & 310 & 314 & 311 & 13210 & 75.70 & 316 & 312 & 316 & 13056 & 76.59 \\
\hline 32 & 31 & 13 & 10.2 & 52.1 & 4.3 & 333 & 335 & 332 & 333 & 13025 & 76.78 & 336 & 336 & 336 & 12922 & 77.39 \\
\hline 33 & 31 & 24 & 9.7 & 47.8 & 4.0 & 307 & 309 & 312 & 309 & 12877 & 77.66 & 304 & 300 & 304 & 13161 & 75.98 \\
\hline 34 & 31 & 28 & 9.8 & 50.5 & 4.2 & 332 & 333 & 328 & 331 & 12714 & 78.65 & 316 & 316 & 316 & 13318 & 75.09 \\
\hline 35 & 31 & 40 & 9.8 & 51.8 & 4.3 & 335 & 336 & 335 & 335 & 12873 & 77.68 & 324 & 320 & 320 & 13434 & 74.44 \\
\hline 36 & 32 & 20 & 9.0 & 44.1 & 3.7 & 292 & 290 & 293 & 292 & 12600 & 79.37 & 284 & 284 & 284 & 12940 & 77.28 \\
\hline 37 & 32 & 26 & 10.4 & 51.6 & 4.3 & 331 & 334 & 335 & 333 & 12900 & 77.52 & 320 & 320 & 320 & 13438 & 74.42 \\
\hline 38 & 35 & 29 & 10.8 & 52.5 & 4.4 & 325 & 322 & 317 & 321 & 13615 & 73.45 & 304 & 304 & 308 & 14329 & 69.79 \\
\hline 39 & 36 & 15 & 11.9 & 47.2 & 3.9 & 303 & 306 & 302 & 304 & 12953 & 77.20 & 300 & 304 & 304 & 12996 & 76.95 \\
\hline 40 & 37 & 7 & 10.5 & 47.5 & 4.0 & 321 & 318 & 319 & 319 & 12396 & 80.67 & 312 & 312 & 316 & 12633 & 79.16 \\
\hline 41 & 38 & 24 & 11.8 & 48.7 & 4.1 & 312 & 314 & 312 & 313 & 12980 & 77.04 & 308 & 300 & 304 & 13350 & 74.91 \\
\hline 42 & 40 & 3 & 9.6 & 51.7 & 4.3 & 321 & 323 & 325 & 323 & 13338 & 74.97 & 316 & 324 & 316 & 13520 & 73.97 \\
\hline 43 & 40 & 17 & 9.6 & 46.0 & 3.8 & 345 & 338 & 342 & 342 & 11220 & 89.13 & 336 & 340 & 340 & 11319 & 88.35 \\
\hline 44 & 40 & 28 & 12.1 & 49.3 & 4.1 & 329 & 331 & 322 & 327 & 12551 & 79.68 & 320 & 320 & 320 & 12839 & 77.89 \\
\hline 45 & 41 & 7 & 9.4 & 47.4 & 4.0 & 322 & 317 & 321 & 320 & 12344 & 81.01 & 324 & 320 & 316 & 12344 & 81.01 \\
\hline 46 & 41 & 10 & 9.4 & 51.4 & 4.3 & 330 & 331 & 330 & 330 & 12967 & 77.12 & 312 & 316 & 316 & 13612 & 73.46 \\
\hline 47 & 42 & 11 & 9.9 & 49.0 & 4.1 & 310 & 316 & 314 & 313 & 13032 & 76.73 & 316 & 308 & 308 & 13144 & 76.08 \\
\hline 48 & 43 & 39 & 10.5 & 46.9 & 3.9 & 322 & 317 & 313 & 317 & 12316 & 81.19 & 312 & 308 & 308 & 12635 & 79.15 \\
\hline 49 & 44 & 7 & 9.8 & 49.9 & 4.2 & 334 & 325 & 327 & 329 & 12652 & 79.04 & 336 & 336 & 336 & 12376 & 80.80 \\
\hline 50 & 44 & 14 & 12.3 & 46.2 & 3.9 & 305 & 306 & 295 & 302 & 12748 & 78.44 & 300 & 296 & 292 & 13007 & 76.88 \\
\hline 51 & 45 & 22 & 12.8 & 44.8 & 3.7 & 318 & 312 & 319 & 316 & 11802 & 84.73 & 324 & 324 & 324 & 11523 & 86.79 \\
\hline 52 & 46 & 4 & 10.3 & 46.1 & 3.8 & 295 & 303 & 305 & 301 & 12763 & 78.35 & 284 & 284 & 284 & 13527 & 73.93 \\
\hline 53 & 46 & 8 & 11.3 & 47.7 & 4.0 & 304 & 302 & 310 & 305 & 13019 & 76.81 & 296 & 296 & 296 & 13429 & 74.47 \\
\hline 54 & 46 & 10 & 10.0 & 47.0 & 3.9 & 298 & 296 & 302 & 299 & 13114 & 76.26 & 284 & 284 & 288 & 13727 & 72.85 \\
\hline 55 & 46 & 40 & 11.2 & 47.9 & 4.0 & 324 & 330 & 328 & 327 & 12195 & 82.00 & 336 & 328 & 324 & 12120 & 82.51 \\
\hline 56 & 47 & 9 & 10.7 & 47.0 & 3.9 & 299 & 301 & 305 & 302 & 12983 & 77.02 & 296 & 292 & 292 & 13352 & 74.89 \\
\hline 57 & 49 & 37 & 13.7 & 45.4 & 3.8 & 319 & 316 & 313 & 316 & 11973 & 83.52 & 304 & 304 & 312 & 12337 & 81.06 \\
\hline 58 & 50 & 2 & 12.6 & 49.2 & 4.1 & 332 & 326 & 331 & 330 & 12437 & 80.41 & 316 & 316 & 316 & 12975 & 77.07 \\
\hline 59 & 52 & 16 & 12.9 & 46.3 & 3.9 & 309 & 300 & 311 & 307 & 12582 & 79.48 & 300 & 300 & 300 & 12861 & 77.75 \\
\hline 60 & 53 & 32 & 7.4 & 44.4 & 3.7 & 346 & 346 & 347 & 346 & 10683 & 93.60 & 352 & 352 & 352 & 10511 & 95.14 \\
\hline 61 & & & 12.7 & 50.0 & 4.2 & 314 & 318 & 321 & 318 & 13116 & 76.24 & 312 & 312 & 312 & 13355 & 74.88 \\
\hline
\end{tabular}


Appendix D. Raw Data.

Red Pine; Arena, Wisconsin

\begin{tabular}{|c|c|c|c|c|c|c|c|c|c|c|}
\hline \multirow[b]{4}{*}{ Tree } & \multicolumn{10}{|c|}{ Log assessment (2/9/05) } \\
\hline & \multicolumn{5}{|c|}{ Dimensions (in) } & \multirow{3}{*}{$\begin{array}{c}\text { Volume } \\
\left(\mathrm{in}^{3}\right)\end{array}$} & \multirow{3}{*}{$\begin{array}{l}\text { Weight } \\
\text { (lb) }\end{array}$} & \multirow{3}{*}{$\begin{array}{c}\text { Average } \\
\text { Density } \\
\left(\mathrm{lb} / \mathrm{ft}^{3}\right)\end{array}$} & \multirow{2}{*}{\multicolumn{2}{|c|}{ Director HM SWS }} \\
\hline & \multirow[b]{2}{*}{ Butt } & \multirow[b]{2}{*}{ Center } & \multirow[b]{2}{*}{ Top } & \multirow[b]{2}{*}{ Diameter } & \multirow[b]{2}{*}{ Radius } & & & & & \\
\hline & & & & & & & & & $\mathrm{ft} / \mathrm{s}$ & $\mu \mathrm{s} / \mathrm{ft}$ \\
\hline 1 & 42.75 & 37.00 & 31.50 & 11.78 & 5.89 & 19609 & 551 & 48.55 & 8793 & 113.73 \\
\hline 3 & 31.75 & 27.75 & 23.50 & 8.83 & 4.42 & 11030 & 301 & 47.15 & 8661 & 115.46 \\
\hline 5 & 33.75 & 31.25 & 30.00 & 9.95 & 4.97 & 13988 & 384 & 47.44 & 10466 & 95.55 \\
\hline 6 & 33.25 & 28.25 & 26.50 & 8.99 & 4.50 & 11431 & 342 & 52.15 & 11188 & 89.38 \\
\hline 7 & 38.50 & 35.50 & 31.25 & 11.30 & 5.65 & 18052 & 487 & 46.62 & 10335 & 96.76 \\
\hline 13 & 32.75 & 29.25 & 27.00 & 9.31 & 4.66 & 12255 & 379 & 53.44 & 10783 & 92.74 \\
\hline 18 & 38.00 & 33.50 & 31.50 & 10.66 & 5.33 & 16075 & 498 & 53.53 & 10225 & 97.80 \\
\hline 20 & 29.50 & 27.25 & 27.00 & 8.67 & 4.34 & 10636 & 309 & 50.20 & 10892 & 91.81 \\
\hline 21 & 32.75 & 28.50 & 26.50 & 9.07 & 4.54 & 11635 & 426 & 63.27 & 11024 & 90.71 \\
\hline 24 & 34.50 & 30.00 & 27.00 & 9.55 & 4.77 & 12892 & 346 & 46.38 & 9843 & 101.60 \\
\hline 25 & 29.50 & 25.25 & 25.00 & 8.04 & 4.02 & 9132 & 265 & 50.14 & 10800 & 92.59 \\
\hline 29 & 27.75 & 25.25 & 23.75 & 8.04 & 4.02 & 9132 & 250 & 47.30 & 11385 & 87.83 \\
\hline 32 & 32.25 & 29.50 & 27.50 & 9.39 & 4.70 & 12465 & 376 & 52.12 & 10892 & 91.81 \\
\hline 35 & 31.00 & 28.00 & 26.25 & 8.91 & 4.46 & 11230 & 333 & 51.24 & 10761 & 92.93 \\
\hline 36 & 28.75 & 27.00 & 25.00 & 8.59 & 4.30 & 10442 & 334 & 55.27 & 11516 & 86.84 \\
\hline 37 & 32.50 & 30.25 & 28.00 & 9.63 & 4.81 & 13107 & 360 & 47.46 & 10203 & 98.01 \\
\hline 44 & 31.71 & 35.95 & 41.13 & 11.44 & 5.72 & 18515 & 499 & 46.57 & 10892 & 91.81 \\
\hline 45 & 32.50 & 27.25 & 25.25 & 8.67 & 4.34 & 10636 & 306 & 49.71 & 10335 & 96.76 \\
\hline 48 & 34.50 & 30.75 & 28.50 & 9.79 & 4.89 & 13544 & 396 & 50.52 & 10827 & 92.36 \\
\hline 49 & 27.75 & 25.00 & 23.00 & 7.96 & 3.98 & 8952 & 254 & 49.03 & 10696 & 93.49 \\
\hline 51 & 41.25 & 38.75 & 31.50 & 12.33 & 6.17 & 21508 & 337 & 27.07 & 9777 & 102.28 \\
\hline 52 & 36.50 & 37.50 & 30.25 & 11.94 & 5.97 & 20143 & 510 & 43.75 & 10761 & 92.93 \\
\hline 53 & 36.00 & 32.00 & 30.00 & 10.19 & 5.09 & 14668 & 438 & 51.60 & 10696 & 93.49 \\
\hline 54 & 33.00 & 29.50 & 28.50 & 9.39 & 4.70 & 12465 & 382 & 52.95 & 10400 & 96.15 \\
\hline 55 & 38.25 & 32.25 & 30.25 & 10.27 & 5.13 & 14898 & 432 & 50.11 & 10039 & 99.61 \\
\hline 56 & 34.50 & 30.25 & 28.75 & 9.63 & 4.81 & 13107 & 384 & 50.62 & 10958 & 91.26 \\
\hline 57 & 47.25 & 39.25 & 39.00 & 12.49 & 6.25 & 22067 & 631 & 49.41 & 9416 & 106.20 \\
\hline 58 & 41.25 & 35.50 & 31.00 & 11.30 & 5.65 & 18052 & 545 & 52.17 & 10138 & 98.64 \\
\hline 59 & 41.50 & 37.50 & 33.75 & 11.94 & 5.97 & 20143 & 559 & 47.95 & 10696 & 93.49 \\
\hline 60 & 24.50 & 19.50 & 16.25 & 6.21 & 3.10 & 5447 & 174 & 55.20 & 9285 & 107.70 \\
\hline
\end{tabular}


Appendix D. Raw Data.

Ponderosa Pine; Boise National Forest, Idaho (9/9/04-9/11/04)

\begin{tabular}{|c|c|c|c|c|c|c|c|}
\hline & & \multicolumn{5}{|c|}{ Speed (ft/s) } \\
\cline { 5 - 8 } Tree No. & DBH (in.) & Scopemeter & Director ST & 1 & 2 & 3 & Avg. \\
\hline 14 & 14.6 & 10417 & 8605 & 7021 & 6923 & 6923 & 6956 \\
15 & 11.3 & 12195 & 10580 & 7776 & 7776 & 7776 & 7765 \\
26 & 11.5 & 9615 & 7850 & 7152 & 7054 & 7054 & 7087 \\
30 & 9.6 & 9091 & 9500 & 12336 & 12336 & 12336 & 6168 \\
31 & 9.2 & 9756 & 8956 & 7644 & 7644 & 7644 & 7644 \\
32 & 7.8 & 8264 & 9762 & 12303 & 12303 & 12303 & 6152 \\
38 & 9.6 & 7407 & 7400 & 12073 & 12073 & 12073 & 6037 \\
39 & 9.1 & 7937 & 7900 & 11745 & 11745 & 11680 & 5862 \\
47 & 12.6 & 10417 & 9500 & 6923 & 6923 & 6824 & 6890 \\
49 & 7.2 & 5882 & 6200 & 9843 & 9843 & 9810 & 4916 \\
50 & 9.1 & 6667 & 5890 & 9580 & 9646 & 9580 & 4808 \\
53 & 8.5 & 9615 & 8067 & 7448 & 7448 & 7415 & 7437 \\
56 & 6.6 & 9259 & 9950 & 6923 & 6923 & 6923 & 6923 \\
69 & 12.3 & 12121 & 10390 & 7940 & 7940 & 7972 & 7951 \\
88 & 11.4 & 10000 & 9864 & 7480 & 7480 & 7480 & 7480 \\
92 & 10.0 & 9091 & 8700 & 6529 & 6529 & 6529 & 6529 \\
99 & 6.6 & 7353 & 7242 & 5774 & 5741 & 5741 & 5752 \\
100 & 7.5 & 9434 & 9532 & 7119 & 7119 & 7119 & 7119 \\
101 & 8.2 & 9091 & 8744 & 6791 & 6791 & 6791 & 6791 \\
102 & 7.6 & 9259 & 8500 & 7152 & 7152 & 7152 & 7152 \\
103 & 7.9 & 7273 & 7858 & 5873 & 5873 & 5873 & 5873 \\
106 & 6.9 & 7273 & 7354 & 5676 & 5577 & 5577 & 5610 \\
111 & 6.8 & 7246 & 6790 & 11680 & 11680 & 11680 & 5840 \\
113 & 7.9 & 9091 & 7529 & 6398 & 6398 & 6398 & 6605 \\
115 & 8.0 & 7246 & 6216 & 5348 & 5348 & 5348 & 5348 \\
\hline
\end{tabular}


Red Oak; Iron County, Missouri

\begin{tabular}{|c|c|c|c|c|c|c|c|c|c|c|}
\hline \multirow[b]{3}{*}{ Tree No. } & \multirow[b]{3}{*}{$\mathrm{DBH}$ (in.) } & \multicolumn{2}{|c|}{$\begin{array}{c}\text { Tree assessment } \\
\text { (laboratory method) }\end{array}$} & \multicolumn{7}{|c|}{ Log assessment (Director HM 200) } \\
\hline & & \multirow{2}{*}{$\begin{array}{l}\text { Stress wave } \\
\text { time }(\mu \mathrm{s})\end{array}$} & \multirow{2}{*}{$\begin{array}{l}\text { wave } \\
\text { speed } \\
(\mu \mathrm{s} / \mathrm{ft})\end{array}$} & \multicolumn{3}{|c|}{ Log length } & \multicolumn{4}{|c|}{ Stress wave speed $(\mu \mathrm{s} / \mathrm{ft})$} \\
\hline & & & & in. & $\mathrm{ft}$ & in. & 1 & 2 & 3 & Average \\
\hline \multicolumn{11}{|c|}{ Red Oak 1 - Doe Run Buick, age 30 years; July 13, 2004} \\
\hline A- 1 & 8.4 & 450 & 112.5 & 129.75 & 10 & 10 & 8432 & 8366 & 8366 & 8388 \\
\hline A- 2 & 6.5 & 352 & 88.0 & 122.50 & 10 & 3 & 9482 & 9482 & 9482 & 9482 \\
\hline A- 3 & 6.5 & 334 & 83.5 & 102.00 & 8 & 6 & 9810 & 9810 & 9810 & 9810 \\
\hline A- 4 & 7.6 & 336 & 84.0 & 126.00 & 10 & 6 & 9449 & 9449 & 9449 & 9449 \\
\hline A- 5 & 7.9 & 360 & 90.0 & 125.50 & 10 & 6 & 8858 & 8858 & 8924 & 8880 \\
\hline A- 6 & 7 & 352 & 88.0 & 121.50 & 10 & 2 & 8924 & 8924 & 8924 & 8924 \\
\hline A- 7 & 7.1 & 328 & 82.0 & 124.75 & 10 & 5 & 10171 & 10171 & 10171 & 10171 \\
\hline A- 8 & 6.5 & 360 & 90.0 & 126.50 & 10 & 7 & 9580 & 9613 & 9580 & 9591 \\
\hline A- 9 & 6.4 & 330 & 82.5 & 122.50 & 10 & 3 & 9744 & 9744 & 9318 & 9602 \\
\hline A- 10 & 7 & 336 & 84.0 & 124.50 & 10 & 5 & 9482 & 9482 & 9482 & 9482 \\
\hline A- 11 & 5.8 & 376 & 94.0 & & & & & & & \\
\hline A- 12 & 7.7 & 384 & 96.0 & & & & & & & \\
\hline A- 13 & 7.3 & 336 & 84.0 & & & & & & & \\
\hline A- 14 & 6.2 & 344 & 86.0 & & & & & & & \\
\hline A- 15 & 7.1 & 376 & 94.0 & & & & & & & \\
\hline A- 16 & 6.1 & 336 & 84.0 & & & & & & & \\
\hline A- 17 & 7 & 336 & 84.0 & & & & & & & \\
\hline A- 18 & 7.8 & 346 & 86.5 & & & & & & & \\
\hline A- 19 & 7.6 & 350 & 87.5 & & & & & & & \\
\hline A- 20 & 7.3 & 338 & 84.5 & & & & & & & \\
\hline A- 21 & 7.1 & 336 & 84.0 & & & & & & & \\
\hline A- 22 & 8.1 & 352 & 88.0 & & & & & & & \\
\hline A- 23 & 7.3 & 344 & 86.0 & & & & & & & \\
\hline A- 24 & 7.9 & 328 & 82.0 & & & & & & & \\
\hline A- 25 & 7.3 & 330 & 82.5 & & & & & & & \\
\hline A- 26 & 6.6 & 320 & 80.0 & & & & & & & \\
\hline A- 27 & 6.9 & 352 & 88.0 & & & & & & & \\
\hline A- 28 & 5.6 & 360 & 90.0 & & & & & & & \\
\hline A- 29 & 7.3 & 350 & 87.5 & & & & & & & \\
\hline A- 30 & 6.7 & 344 & 86.0 & & & & & & & \\
\hline \multicolumn{11}{|c|}{ Red Oak 2 - B-Day, age 60+ years; July 14, 2004} \\
\hline A- 31 & 11.6 & 347 & 86.8 & 126.50 & 10 & 7 & 9613 & 9613 & 9613 & 9613 \\
\hline A- 32 & 9 & 340 & 85.0 & 128.00 & 10 & 8 & 9416 & 9416 & 9416 & 9416 \\
\hline A- 33 & 9.1 & 376 & 94.0 & & & & & & & \\
\hline A- 34 & 10.6 & 416 & 104.0 & 127.50 & 10 & 8 & 8235 & 8235 & 8235 & 8235 \\
\hline A- 35 & 9.1 & 350 & 87.5 & 128.75 & 10 & 9 & 9383 & 9383 & 9383 & 9383 \\
\hline A- 36 & 10.1 & 368 & 92.0 & & & & & & & \\
\hline A- 37 & 10.5 & 360 & 90.0 & & & & & & & \\
\hline A- 38 & 11.3 & 360 & 90.0 & & & & & & & \\
\hline A- 39 & 6.3 & 372 & 93.0 & & & & & & & \\
\hline A- 40 & 10.1 & 416 & 104.0 & 127.25 & 10 & 7 & 8071 & 8071 & 8071 & 8071 \\
\hline A- 41 & 12 & 360 & 90.0 & & & & & & & \\
\hline A- 42 & 9.8 & 380 & 95.0 & & & & & & & \\
\hline A- 43 & 9.6 & 368 & 92.0 & & & & & & & \\
\hline A- 44 & 6.5 & 352 & 88.0 & 125.50 & 10 & 6 & 8038 & 8038 & 8038 & 8038 \\
\hline A- 45 & 7.7 & 370 & 92.5 & & & & & & & \\
\hline A- 46 & 9.9 & 364 & 91.0 & & & & & & & \\
\hline A- 47 & 8.1 & 352 & 88.0 & 126.25 & 10 & 6 & 8957 & 8957 & 8957 & 8957 \\
\hline A- 48 & 7.2 & 376 & 94.0 & & & & & & & \\
\hline A- 49 & 7.7 & 368 & 92.0 & 127.00 & 10 & 7 & 8694 & 8694 & 8694 & 8694 \\
\hline A- 50 & 10 & 360 & 90.0 & & & & & & & \\
\hline A- 51 & 7.9 & 424 & 106.0 & 128.00 & 10 & 8 & 7349 & 7349 & 7349 & 7349 \\
\hline A- 52 & 10.5 & 364 & 91.0 & & & & & & & \\
\hline A- 53 & 5.9 & 390 & 97.5 & & & & & & & \\
\hline A- 54 & 8.1 & 352 & 88.0 & & & & & & & \\
\hline A- 55 & 8.2 & 380 & 95.0 & & & & & & & \\
\hline A- 56 & 8 & 360 & 90.0 & & & & & & & \\
\hline A- 57 & 9.5 & 368 & 92.0 & & & & & & & \\
\hline
\end{tabular}


Red Oak; Iron County, Missouri

\begin{tabular}{|c|c|c|c|c|c|c|c|c|c|c|}
\hline \multirow[b]{3}{*}{ Tree No. } & \multirow[b]{3}{*}{ DBH (in.) } & \multicolumn{2}{|c|}{$\begin{array}{l}\text { Tree assessment } \\
\text { (laboratory method) }\end{array}$} & \multicolumn{7}{|c|}{ Log assessment (Director HM 200) } \\
\hline & & \multirow{2}{*}{$\begin{array}{l}\text { Stress wave } \\
\text { time }(\mu \mathrm{s})\end{array}$} & \multirow{2}{*}{$\begin{array}{l}\text { wave } \\
\text { speed } \\
(\mu \mathrm{s} / \mathrm{ft})\end{array}$} & \multicolumn{3}{|c|}{ Log length } & \multicolumn{4}{|c|}{ Stress wave speed ( $\mu \mathrm{s} / \mathrm{ft})$} \\
\hline & & & & in. & $\mathrm{ft}$ & in. & 1 & 2 & 3 & Average \\
\hline A- 58 & 9.8 & 360 & 90.0 & & & & & & & \\
\hline A- 59 & 8.9 & 354 & 88.5 & 126.50 & 10 & 7 & 9482 & 9482 & 9482 & 9482 \\
\hline A- 60 & 9.9 & 392 & 98.0 & 127.25 & 10 & 7 & 8399 & 8399 & 8399 & 8399 \\
\hline \multicolumn{11}{|c|}{ Red Oak 3 - Logan, July 15, 2004} \\
\hline A- 61 & 10 & 392 & 98.0 & & & & & & & \\
\hline A- 62 & 11.3 & 384 & 96.0 & & & & & & & \\
\hline A- 63 & 11.2 & 336 & 84.0 & & & & & & & \\
\hline A- 64 & 13.1 & 320 & 80.0 & 127.50 & 10 & 8 & 10958 & 10958 & 10958 & 10958 \\
\hline A- 65 & 7.7 & 336 & 84.0 & & & & & & & \\
\hline A- 66 & 12.8 & 368 & 92.0 & & & & & & & \\
\hline A- 67 & 12 & 390 & 97.5 & 127.50 & 10 & 8 & 9088 & 9088 & 9088 & 9088 \\
\hline A- 68 & 6.7 & 360 & 90.0 & 128.75 & 10 & 9 & 9383 & 8825 & 9383 & 9197 \\
\hline A- 69 & 10.1 & 360 & 90.0 & 126.25 & 10 & 6 & 9252 & 9252 & 9252 & 9252 \\
\hline A- 70 & 11.3 & 368 & 92.0 & & & & & & & \\
\hline A- 71 & 8.9 & 376 & 94.0 & & & & & & & \\
\hline A- 72 & 8.8 & 352 & 88.0 & 127.50 & 10 & 8 & 9088 & 9088 & 9154 & 9110 \\
\hline A- 73 & 11.1 & 376 & 94.0 & & & & & & & \\
\hline A- 74 & 8 & 336 & 84.0 & & & & & & & \\
\hline A- 75 & 10.5 & 334 & 83.5 & & & & & & & \\
\hline A- 76 & 10.3 & 416 & 104.0 & 130.00 & 10 & 10 & 7907 & 7972 & 7972 & 7950.3 \\
\hline A- 77 & 9.4 & 352 & 88.0 & 129.00 & 10 & 9 & 9777 & 9777 & 9777 & 9777 \\
\hline A- 78 & 9.5 & 320 & 80.0 & & & & & & & \\
\hline A- 79 & 11.9 & 328 & 82.0 & & & & & & & \\
\hline A- 80 & 11.2 & 336 & 84.0 & & & & & & & \\
\hline A- 81 & 9.2 & 368 & 92.0 & 120.50 & 10 & 7 & 9908 & 9908 & 9908 & 9908 \\
\hline A- 82 & 10.2 & 328 & 82.0 & & & & & & & \\
\hline A- 83 & 9.1 & 392 & 98.0 & 128.50 & 10 & 9 & 8465 & 8465 & 8465 & 8465 \\
\hline A- 84 & 9.2 & 328 & 82.0 & & & & & & & \\
\hline A- 85 & 9.5 & 304 & 76.0 & 128.00 & 10 & 8 & 11352 & 11352 & 11352 & 11352 \\
\hline A- 86 & 10.3 & 344 & 86.0 & & & & & & & \\
\hline A- 87 & 8.4 & 344 & 86.0 & & & & & & & \\
\hline A- 88 & 8.7 & 368 & 92.0 & & & & & & & \\
\hline A- 89 & 10.5 & 380 & 95.0 & & & & & & & \\
\hline A- 90 & 8.2 & 376 & 94.0 & & & & & & & \\
\hline
\end{tabular}


Appendix D. Raw Data.

Radiata Pine; Australia

\begin{tabular}{|c|c|c|c|c|c|c|c|}
\hline \multicolumn{4}{|c|}{ Radiata Pine 1} & \multicolumn{4}{|c|}{ Radiata pine 2} \\
\hline \multirow[b]{2}{*}{ Tree No. } & \multicolumn{3}{|c|}{ Velocity (ft/s) } & \multirow[b]{2}{*}{ Tree No. } & \multicolumn{3}{|c|}{ Velocity (ft/s) } \\
\hline & Scopemeter & ST 300 & HM 200 & & Scopemeter & ST 300 & $\mathrm{HM} 200$ \\
\hline 1 & 12985 & 12951 & 8530 & 41 & 14952 & 14913 & 11221 \\
\hline 2 & 12652 & 12619 & 8858 & 42 & 14952 & 14913 & 11975 \\
\hline 3 & 11748 & 11718 & 8235 & 43 & 14952 & 14913 & 11155 \\
\hline 5 & 12985 & 12951 & 8760 & 44 & 14098 & 14061 & 10466 \\
\hline 6 & 11748 & 11718 & 8596 & 45 & 14098 & 14061 & 10564 \\
\hline 7 & 11475 & 11445 & 8005 & 46 & 14098 & 14061 & 10925 \\
\hline 8 & 12336 & 12303 & 8465 & 47 & 14512 & 14475 & 10696 \\
\hline 9 & 10727 & 10699 & 8071 & 48 & 13336 & 13301 & 9941 \\
\hline 10 & 10965 & 10936 & 8891 & 49 & 14098 & 14061 & 11089 \\
\hline 11 & 12035 & 12003 & 8596 & 50 & 14098 & 14061 & 10761 \\
\hline 12 & 12985 & 12951 & 8858 & 52 & 14098 & 14061 & 10466 \\
\hline 13 & 12652 & 12619 & 8366 & 53 & 14098 & 14061 & 10860 \\
\hline 14 & 10727 & 10699 & 7612 & 54 & 13706 & 13670 & 10761 \\
\hline 15 & 11214 & 11185 & 8137 & 55 & 14098 & 14061 & 11746 \\
\hline 16 & 12035 & 12003 & 8694 & 56 & 15419 & 15379 & 11221 \\
\hline 17 & 11748 & 11718 & 8694 & 57 & 14952 & 14913 & 10860 \\
\hline 18 & 11475 & 11445 & 8038 & 58 & 12985 & 12951 & 10991 \\
\hline 19 & 12108 & 12077 & 8596 & 59 & 14952 & 14913 & 10925 \\
\hline 20 & 12652 & 12619 & 8760 & 60 & 13899 & 13863 & 11155 \\
\hline 21 & 11542 & 11512 & 8530 & 61 & 13336 & 13301 & 10400 \\
\hline 22 & 12035 & 12003 & 8924 & 62 & 14952 & 14913 & 11746 \\
\hline 23 & 11818 & 11788 & 8694 & 63 & 12413 & 12381 & 10105 \\
\hline 24 & 12183 & 12151 & 9088 & 64 & 14620 & 14582 & 10564 \\
\hline 25 & 11962 & 11931 & 8760 & 65 & 13706 & 13670 & 10696 \\
\hline 26 & 11610 & 11580 & 8301 & 66 & 14620 & 14582 & 10761 \\
\hline 27 & 12413 & 12381 & 8858 & 67 & 12733 & 12700 & 9351 \\
\hline 28 & 12652 & 12619 & 8235 & 68 & 14729 & 14691 & 11089 \\
\hline 29 & 11890 & 11859 & 8366 & 69 & 11343 & 11313 & 9580 \\
\hline 30 & 11542 & 11512 & 8235 & 70 & 14729 & 14691 & 11089 \\
\hline 31 & 11278 & 11249 & 7612 & 71 & 13899 & 13863 & 10564 \\
\hline 32 & 11818 & 11788 & 8366 & 72 & 13998 & 13961 & 10860 \\
\hline 33 & 11343 & 11313 & 7841 & 73 & 12900 & 12866 & 9810 \\
\hline 34 & 12492 & 12459 & 8858 & 74 & 13802 & 13766 & 10466 \\
\hline 35 & 11962 & 11931 & 8530 & 75 & 13899 & 13863 & 11155 \\
\hline 36 & 11818 & 11788 & 8530 & 76 & 13899 & 13863 & 11516 \\
\hline 37 & 11475 & 11445 & 7546 & 77 & 13426 & 13391 & 10236 \\
\hline 38 & 12108 & 12077 & 8235 & 78 & 15066 & 15027 & 10925 \\
\hline 39 & 12336 & 12303 & 8530 & 79 & 13071 & 13037 & 10466 \\
\hline 40 & 12336 & 12303 & 8596 & 80 & 14406 & 14369 & 11089 \\
\hline
\end{tabular}


Appendix D. Raw Data.

Radiata Pine; Australia

\begin{tabular}{|c|c|c|c|c|c|c|c|}
\hline \multicolumn{4}{|c|}{ Radiata pine 3} & \multicolumn{4}{|c|}{ Radiata pine 4} \\
\hline \multirow[b]{2}{*}{ Tree No. } & \multicolumn{3}{|c|}{ Velocity (ft/s) } & \multirow[b]{2}{*}{ Tree No. } & \multicolumn{3}{|c|}{ Velocity (ft/s) } \\
\hline & Scopemeter & ST 300 & HM 200 & & Scopemeter & ST 300 & HM 200 \\
\hline 81 & 14098 & 14061 & 10893 & 121 & 14512 & 14475 & 11188 \\
\hline 82 & 12652 & 12619 & 11549 & 122 & 14098 & 14061 & 11319 \\
\hline 83 & 15419 & 15379 & 11844 & 123 & 14952 & 14913 & 12074 \\
\hline 84 & 14952 & 14913 & 11778 & 124 & 14098 & 14061 & 11844 \\
\hline 86 & 15419 & 15379 & 11844 & 125 & 13518 & 13483 & 10630 \\
\hline 87 & 13336 & 13301 & 11057 & 126 & 13706 & 13670 & 11418 \\
\hline 88 & 14952 & 14913 & 11385 & 127 & 13518 & 13483 & 11418 \\
\hline 89 & 13706 & 13670 & 11549 & 128 & 12985 & 12951 & 11221 \\
\hline 90 & 14512 & 14475 & 10761 & 129 & 13336 & 13301 & 10499 \\
\hline 91 & 15419 & 15379 & 11647 & 130 & 13706 & 13670 & 11483 \\
\hline 92 & 14512 & 14475 & 11155 & 131 & 14302 & 14265 & 12271 \\
\hline 93 & 14952 & 14913 & 11614 & 132 & 13518 & 13483 & 12074 \\
\hline 94 & 15419 & 15379 & 11680 & 133 & 14302 & 14265 & 12205 \\
\hline 95 & 14952 & 14913 & 12271 & 134 & 13518 & 13483 & 11057 \\
\hline 96 & 14952 & 14913 & 11385 & 135 & 14302 & 14265 & 11844 \\
\hline 97 & 14512 & 14475 & 12074 & 136 & 14512 & 14475 & 11910 \\
\hline 98 & 14512 & 14475 & 11450 & 137 & 13899 & 13863 & 11647 \\
\hline 99 & 15419 & 15379 & 11680 & 138 & 14512 & 14475 & 11778 \\
\hline 100 & 15917 & 15875 & 12139 & 139 & 13899 & 13863 & 11450 \\
\hline 101 & 14512 & 14475 & 11910 & 140 & 14512 & 14475 & 11221 \\
\hline 102 & 14512 & 14475 & 10729 & 141 & 14302 & 14265 & 12664 \\
\hline 103 & 14952 & 14913 & 11385 & 142 & 14302 & 14265 & 11155 \\
\hline 104 & 14098 & 14061 & 10827 & 143 & 13158 & 13124 & 11024 \\
\hline 105 & 14952 & 14913 & 11057 & 144 & 14098 & 14061 & 12303 \\
\hline 106 & 14512 & 14475 & 11549 & 145 & 13518 & 13483 & 11483 \\
\hline 107 & 14512 & 14475 & 11647 & 146 & 13706 & 13670 & 11352 \\
\hline 108 & 14098 & 14061 & 11778 & 147 & 14512 & 14475 & 12139 \\
\hline 109 & 14512 & 14475 & 11385 & 148 & 12985 & 12951 & 10860 \\
\hline 110 & 14512 & 14475 & 12008 & 149 & 13158 & 13124 & 11221 \\
\hline 111 & 14098 & 14061 & 11778 & 150 & 13899 & 13863 & 11221 \\
\hline 112 & 14098 & 14061 & 11155 & 151 & 13899 & 13863 & 11188 \\
\hline 113 & 14512 & 14475 & 11549 & 152 & 14098 & 14061 & 11713 \\
\hline 114 & 14512 & 14475 & 11319 & 153 & 14098 & 14061 & 11975 \\
\hline 115 & 14512 & 14475 & 11089 & 154 & 14302 & 14265 & 12205 \\
\hline 116 & 14512 & 14475 & 11910 & 155 & 14512 & 14475 & 11811 \\
\hline 117 & 14098 & 14061 & 11319 & 156 & 13899 & 13863 & 11385 \\
\hline 118 & 14512 & 14475 & 12303 & 157 & 13706 & 13670 & 11680 \\
\hline 119 & 14098 & 14061 & 11385 & 158 & 14098 & 14061 & 11811 \\
\hline 120 & 14098 & 14061 & 10761 & 159 & 14302 & 14265 & 12139 \\
\hline & & & & 160 & 13706 & 13670 & 11483 \\
\hline
\end{tabular}


Radiata Pine; New Zealand

\begin{tabular}{|c|c|c|c|c|c|c|c|c|c|c|c|}
\hline \multicolumn{4}{|c|}{ Radiata Pine 5} & \multicolumn{4}{|c|}{ Radiata Pine 6} & \multicolumn{4}{|c|}{ Radiata Pine 7} \\
\hline \multirow[b]{2}{*}{ Tree No. } & \multicolumn{3}{|c|}{ Velocity (ft/s) } & \multirow[b]{2}{*}{ Tree No. } & \multicolumn{3}{|c|}{ Velocity (ft/s) } & \multirow[b]{2}{*}{ Tree No. } & \multicolumn{3}{|c|}{ Velocity (ft/s) } \\
\hline & Scopemeter & ST 300 & HM 200 & & Scopemeter & ST 300 & $\mathrm{HM} 200$ & & Scopemeter & ST 300 & $\mathrm{HM} 200$ \\
\hline 1 & 4623 & 4623 & 4560 & 51 & 7510 & 7510 & 7776 & 101 & 9045 & 9046 & 7776 \\
\hline 2 & 5249 & 5249 & 4987 & 52 & 6769 & 6769 & 6562 & 102 & 9776 & 9776 & 8333 \\
\hline 3 & 6147 & 6148 & 6201 & 53 & 7510 & 7510 & 7087 & 103 & 9045 & 9046 & 8137 \\
\hline 4 & 6508 & 6508 & 5840 & 54 & 8408 & 8408 & 8301 & 104 & 8214 & 8214 & 6726 \\
\hline 5 & 6147 & 6148 & 5774 & 55 & 8027 & 8027 & 7612 & 105 & 8214 & 8214 & 7415 \\
\hline 6 & 5546 & 5546 & 5643 & 56 & 7350 & 7351 & 7382 & 106 & 11264 & 11264 & 9613 \\
\hline 7 & 5249 & 5249 & 5413 & 57 & 7510 & 7510 & 7677 & 107 & 9521 & 9521 & 8563 \\
\hline 8 & 6636 & 6636 & 6332 & 58 & 7197 & 7197 & 6627 & 108 & 8408 & 8408 & 7415 \\
\hline 9 & 6147 & 6148 & 6135 & 59 & 8408 & 8408 & 8071 & 109 & 9278 & 9278 & 8760 \\
\hline 10 & 5926 & 5926 & 5643 & 60 & 7510 & 7510 & 7546 & 110 & 9045 & 9046 & 7907 \\
\hline 11 & 5338 & 5338 & 5282 & 61 & 7675 & 7676 & 7448 & 111 & 7675 & 7676 & 6627 \\
\hline 12 & 6035 & 6035 & 6037 & 62 & 8027 & 8027 & 8137 & 112 & 8214 & 8214 & 7907 \\
\hline 13 & 4919 & 4920 & 5053 & 63 & 7197 & 7197 & 6923 & 113 & 10044 & 10044 & 9121 \\
\hline 14 & 4919 & 4920 & 5151 & 64 & 7197 & 7197 & 7152 & 114 & 10325 & 10325 & 8990 \\
\hline 15 & 6769 & 6769 & 5971 & 65 & 6508 & 6508 & 6496 & 115 & 10044 & 10044 & 8629 \\
\hline 16 & 5926 & 5926 & 5709 & 66 & 6769 & 6769 & 6037 & 116 & 8824 & 8824 & 7415 \\
\hline 17 & 7510 & 7510 & 6627 & 67 & 7350 & 7351 & 7087 & 117 & 10622 & 10622 & 9482 \\
\hline 18 & 7049 & 7049 & 6956 & 68 & 8408 & 8408 & 7776 & 118 & 8824 & 8824 & 8137 \\
\hline 19 & 6035 & 6035 & 6135 & 69 & 8027 & 8027 & 7907 & 119 & 8611 & 8612 & 7841 \\
\hline 20 & 5429 & 5429 & 5610 & 70 & 6906 & 6907 & 6693 & 120 & 9521 & 9521 & 9187 \\
\hline 21 & 6147 & 6148 & 5971 & 71 & 6636 & 6636 & 6857 & 121 & 8611 & 8612 & 7579 \\
\hline 22 & 5522 & 5522 & 5413 & 72 & 8611 & 8612 & 7480 & 122 & 9278 & 9278 & 8333 \\
\hline 23 & 5080 & 5080 & 5151 & 73 & 8027 & 8027 & 8366 & 123 & 7675 & 7676 & 7644 \\
\hline 24 & 6383 & 6384 & 6102 & 74 & 9045 & 9046 & 7907 & 124 & 7510 & 7510 & 6857 \\
\hline 25 & 7197 & 7197 & 6693 & 75 & 6636 & 6636 & 6398 & 125 & 9521 & 9521 & 7907 \\
\hline 26 & 6035 & 6035 & 5643 & 76 & 6383 & 6384 & 6791 & 126 & 8408 & 8408 & 6463 \\
\hline 27 & 6263 & 6264 & 6332 & 77 & 6769 & 6769 & 7087 & 127 & 10325 & 10325 & 8694 \\
\hline 28 & 6147 & 6148 & 6201 & 78 & 6906 & 6907 & 6857 & 128 & 8214 & 8214 & 7415 \\
\hline 29 & 5926 & 5926 & 5774 & 79 & 8611 & 8612 & 8071 & 129 & 8824 & 8824 & 8498 \\
\hline 30 & 6035 & 6035 & 5906 & 80 & 7049 & 7049 & 6693 & 130 & 9045 & 9046 & 8137 \\
\hline 31 & 7049 & 7049 & 6627 & 81 & 6769 & 6769 & 6102 & 131 & 8824 & 8824 & 7513 \\
\hline 32 & 5820 & 5821 & 6135 & 82 & 7197 & 7197 & 7087 & 132 & 10044 & 10044 & 8005 \\
\hline 33 & 5926 & 5926 & 5709 & 83 & 6906 & 6907 & 6693 & 133 & 12373 & 12373 & 9351 \\
\hline 34 & 5249 & 5249 & 5282 & 84 & 7197 & 7197 & 6627 & 134 & 9278 & 9278 & 8498 \\
\hline 35 & 5163 & 5164 & 5118 & 85 & 8611 & 8612 & 7841 & 135 & 9278 & 9278 & 8005 \\
\hline 36 & 4999 & 4999 & 4921 & 86 & 8408 & 8408 & 7677 & 136 & 8408 & 8408 & 8202 \\
\hline 37 & 6383 & 6384 & 5906 & 87 & 7049 & 7049 & 6791 & 137 & 8824 & 8824 & 7907 \\
\hline 38 & 7049 & 7049 & 6463 & 88 & 6263 & 6264 & 5643 & 138 & 8027 & 8027 & 6988 \\
\hline 39 & 5080 & 5080 & 5545 & 89 & 9045 & 8027 & 7546 & 139 & 8214 & 8214 & 8005 \\
\hline 40 & 5926 & 5926 & 5545 & 90 & 9045 & 9046 & 8366 & 140 & 8214 & 8214 & 7415 \\
\hline 41 & 5163 & 5164 & 5348 & 91 & 7675 & 9046 & 8137 & 141 & 8611 & 8612 & 7284 \\
\hline 42 & 5080 & 5080 & 5151 & 92 & 7675 & 7676 & 7382 & 142 & 9278 & 9278 & 7710 \\
\hline 43 & 6383 & 6384 & 6201 & 93 & 6636 & 7676 & 7907 & 143 & 9521 & 9521 & 7349 \\
\hline 44 & 4355 & 4355 & 4626 & 94 & 6636 & 6636 & 6168 & 144 & 9521 & 9521 & 8202 \\
\hline 45 & 6383 & 6384 & 5971 & 95 & 5429 & 6636 & 6627 & 145 & 9776 & 9776 & 8202 \\
\hline 46 & 4623 & 4623 & 4889 & 96 & 7350 & 5429 & 5479 & 146 & 9045 & 9046 & 8137 \\
\hline 47 & 5820 & 5821 & 5643 & 97 & 8214 & 7351 & 6627 & 147 & 9776 & 9776 & 7710 \\
\hline 48 & 4623 & 4623 & 4724 & 98 & 6383 & 8214 & 7152 & 148 & 9521 & 9521 & 8333 \\
\hline 49 & 4419 & 4420 & 4626 & 99 & 7510 & 6384 & 6332 & 149 & 8824 & 8824 & 8498 \\
\hline 50 & 4694 & 4694 & 4790 & 100 & 6897 & 7510 & 7021 & 150 & 11264 & 11264 & 9187 \\
\hline
\end{tabular}


Radiata Pine; New Zealand

\begin{tabular}{|c|c|c|c|c|c|c|c|c|}
\hline \multicolumn{3}{|c|}{ Radiata Pine 8} & \multicolumn{6}{|c|}{ Radiata Pine 9} \\
\hline \multirow[b]{2}{*}{ Tree } & \multicolumn{2}{|c|}{ Velocity (ft/s) } & \multirow[b]{2}{*}{ Tree } & \multicolumn{2}{|c|}{ Velocity (ft/s) } & \multirow[b]{2}{*}{ Tree } & \multicolumn{2}{|c|}{ Velocity (ft/s) } \\
\hline & ST 300 & HM 200 & & ST 300 & HM 200 & & ST 300 & HM 200 \\
\hline 151 & 6614 & 5578 & 201 & 8298 & 7260 & 247 & 7939 & 7005 \\
\hline 152 & 6942 & 6595 & 202 & 7741 & 6614 & 248 & 6805 & 5850 \\
\hline 153 & 5919 & 5414 & 203 & 8075 & 6942 & 249 & 9245 & 8247 \\
\hline 154 & 5823 & 5414 & 204 & 6587 & 5919 & 250 & 7215 & 6281 \\
\hline 155 & 6083 & 5709 & 205 & 6626 & 5823 & 251 & 8298 & 7260 \\
\hline 156 & 6986 & 5906 & 206 & 7007 & 6083 & 252 & 7741 & 6614 \\
\hline 157 & 6892 & 6103 & 207 & 7899 & 6986 & 253 & 8075 & 6942 \\
\hline 158 & 6596 & 5971 & 208 & 7733 & 6892 & 254 & 6587 & 5919 \\
\hline 159 & 7143 & 6037 & 209 & 7340 & 6596 & 255 & 6626 & 5823 \\
\hline 160 & 7372 & 6562 & 210 & 7783 & 7143 & 256 & 7007 & 6083 \\
\hline 161 & 7662 & 6956 & 211 & 8445 & 7372 & 257 & 7899 & 6986 \\
\hline 162 & 7410 & 6529 & 212 & 8737 & 7662 & 258 & 7733 & 6892 \\
\hline 163 & 7326 & 6398 & 213 & 8307 & 7410 & 259 & 7340 & 6596 \\
\hline 164 & 6693 & 5742 & 214 & 8263 & 7326 & 260 & 7783 & 7143 \\
\hline 165 & 6121 & 5184 & 215 & 7615 & 6693 & 261 & 8445 & 7372 \\
\hline 166 & 5809 & 5282 & 216 & 6897 & 6121 & 262 & 8737 & 7662 \\
\hline 167 & 5222 & 4922 & 217 & 6439 & 5809 & 263 & 8307 & 7410 \\
\hline 168 & 6454 & 5643 & 218 & 5879 & 5222 & 264 & 8263 & 7326 \\
\hline 169 & 6619 & 5709 & 219 & 7273 & 6454 & 265 & 7615 & 6693 \\
\hline 170 & 5921 & 5250 & 220 & 7565 & 6619 & 266 & 6897 & 6121 \\
\hline 171 & 6663 & 6168 & 221 & 6715 & 5921 & 267 & 6439 & 5809 \\
\hline 172 & 7293 & 6135 & 222 & 7707 & 6663 & 268 & 5879 & 5222 \\
\hline 173 & 5850 & 5217 & 223 & 7964 & 7293 & 269 & 7273 & 6454 \\
\hline 176 & 5660 & 5118 & 224 & 7704 & 6623 & 270 & 6715 & 5921 \\
\hline 177 & 6272 & 5643 & 225 & 6321 & 5660 & 271 & 7707 & 6663 \\
\hline 178 & 6673 & 5906 & 226 & 7264 & 6272 & 272 & 7964 & 7293 \\
\hline 179 & 6918 & 6332 & 227 & 7526 & 6673 & 273 & 7565 & 6619 \\
\hline 180 & 5688 & 5414 & 228 & 7795 & 6918 & & & \\
\hline 181 & 6570 & 6267 & 229 & 6561 & 5688 & & & \\
\hline 182 & 6435 & 5611 & 230 & 7707 & 6570 & & & \\
\hline 183 & 6676 & 5971 & 231 & 7466 & 6435 & & & \\
\hline 184 & 7136 & 6332 & 232 & 7664 & 6676 & & & \\
\hline 185 & 5808 & 5184 & 233 & 7963 & 7136 & & & \\
\hline 186 & 6623 & 5512 & 234 & 6550 & 5808 & & & \\
\hline 187 & 7128 & 5971 & 235 & 7564 & 6623 & & & \\
\hline 188 & 7038 & 6037 & 236 & 8165 & 7128 & & & \\
\hline 189 & 7608 & 6267 & 237 & 7839 & 7038 & & & \\
\hline 190 & 5640 & 5217 & 238 & 8573 & 7608 & & & \\
\hline 191 & 6460 & 5643 & 239 & 6456 & 5640 & & & \\
\hline 192 & 6318 & 5676 & 240 & 7248 & 6460 & & & \\
\hline 193 & 5874 & 5184 & 241 & 7188 & 6318 & & & \\
\hline 194 & 6975 & 6332 & 242 & 6714 & 5874 & & & \\
\hline 195 & 6148 & 5873 & 243 & 8046 & 6975 & & & \\
\hline 196 & 7823 & 6496 & 244 & 7224 & 6148 & & & \\
\hline 197 & 6774 & 5807 & 245 & 9089 & 7823 & & & \\
\hline 198 & 7005 & 6201 & 246 & 7659 & 6774 & & & \\
\hline
\end{tabular}


Appendix D. Raw Data.

Douglas fir; Oregon

Slash Pine; Louisiana

\begin{tabular}{|c|c|c|c|c|c|c|c|c|c|}
\hline \multicolumn{6}{|c|}{ Velocity (ft/s) } & \multicolumn{4}{|c|}{ Velocity (ft/s) } \\
\hline \multicolumn{2}{|c|}{ Douglas fir $A$} & \multicolumn{2}{|c|}{ Douglas fir B } & \multicolumn{2}{|c|}{ Douglas fir C } & \multicolumn{2}{|c|}{ Slash Pine $A$} & \multicolumn{2}{|c|}{ Slash Pine B } \\
\hline ST 300 & HM 200 & ST 300 & HM 200 & ST 300 & HM 200 & ST 300 & HM 200 & ST 300 & HM 200 \\
\hline 13463 & 11600 & 14631 & 12400 & 14760 & 13416 & 11429 & 8596 & 12658 & 10302 \\
\hline 14758 & 13156 & 14915 & 13100 & 13476 & 12894 & 11299 & 8629 & 13158 & 10531 \\
\hline 13052 & 12008 & 14140 & 12500 & 14241 & 12566 & 11236 & 8694 & 12987 & 10630 \\
\hline 14202 & 12566 & 15485 & 13500 & 13672 & 12730 & 10989 & 9121 & 13333 & 10892 \\
\hline 14200 & 12894 & 14151 & 12200 & 13810 & 12402 & 12739 & 9219 & 13514 & 10925 \\
\hline 14500 & 12894 & 13579 & 12200 & 13036 & 12566 & 10870 & 9252 & 13699 & 10925 \\
\hline 12182 & 12000 & 14419 & 12500 & 13804 & 13222 & 13158 & 9613 & 13889 & 11024 \\
\hline 13346 & 11900 & 15278 & 12600 & 13511 & 12566 & 11628 & 9711 & 14085 & 11122 \\
\hline 13668 & 11900 & 14400 & 13500 & 13415 & 13058 & 13699 & 9941 & 14085 & 11220 \\
\hline 14104 & 13000 & 14953 & 13222 & 13971 & 13648 & 13333 & 10116 & 14085 & 11319 \\
\hline 13715 & 12800 & 15196 & 13714 & 13810 & 13222 & 13605 & 10269 & 13699 & 11516 \\
\hline 14189 & 12666 & 12928 & 11900 & 15440 & 14370 & 13333 & 10433 & 14286 & 11909 \\
\hline 13724 & 12730 & 14982 & 13058 & 14429 & 13320 & 12821 & 10499 & 14286 & 11909 \\
\hline 13800 & 12500 & 13101 & 12894 & 14736 & 13156 & 13514 & 10674 & 14925 & 11942 \\
\hline 14000 & 12894 & 13205 & 12073 & 13454 & 13386 & 12658 & 10958 & 13699 & 11992 \\
\hline 13800 & 12008 & 12909 & 11745 & 13798 & 13714 & 14085 & 11056 & 14493 & 12106 \\
\hline 14600 & 13320 & 15029 & 13386 & 13749 & 13322 & 13514 & 11122 & 14706 & 12139 \\
\hline 13300 & 12664 & 14716 & 12730 & 14750 & 13812 & 14388 & 11155 & 14493 & 12139 \\
\hline 14300 & 12336 & 14436 & 12828 & 13487 & 13320 & 13158 & 11385 & 14493 & 12205 \\
\hline 14240 & 12730 & 14540 & 12500 & 13790 & 13320 & 14493 & 11395 & 14706 & 12303 \\
\hline 13719 & 11680 & 14694 & 12700 & & & 14493 & 11527 & 14085 & 12369 \\
\hline 15388 & 12008 & 14251 & 13100 & & & 14925 & 11833 & 14706 & 12434 \\
\hline 14341 & 12566 & 15156 & 14000 & & & 15152 & 11953 & 14493 & 12434 \\
\hline 14052 & 13222 & 14439 & 13222 & & & 14085 & 12073 & 14706 & 12500 \\
\hline 13212 & 12402 & 14757 & 12700 & & & 13889 & 12106 & & \\
\hline 14032 & 12238 & 13101 & 12700 & & & & & & \\
\hline 14530 & 12992 & & & & & & & & \\
\hline 13803 & 12336 & & & & & & & & \\
\hline 14006 & 12402 & & & & & & & & \\
\hline 14309 & 12828 & & & & & & & & \\
\hline 14778 & 13189 & & & & & & & & \\
\hline 13734 & 12336 & & & & & & & & \\
\hline 14367 & 12664 & & & & & & & & \\
\hline 14403 & 12992 & & & & & & & & \\
\hline 14481 & 12664 & & & & & & & & \\
\hline 14373 & 12664 & & & & & & & & \\
\hline 14494 & 13156 & & & & & & & & \\
\hline 13110 & 12073 & & & & & & & & \\
\hline 14196 & 12238 & & & & & & & & \\
\hline 15073 & 13550 & & & & & & & & \\
\hline 13400 & 12073 & & & & & & & & \\
\hline 14069 & 13484 & & & & & & & & \\
\hline 14130 & 13320 & & & & & & & & \\
\hline 13156 & 12372 & & & & & & & & \\
\hline 13550 & 13196 & & & & & & & & \\
\hline
\end{tabular}


Appendix D. Raw Data.

Alaska, Michigan, Oregon and Louisiana data

\begin{tabular}{|c|c|c|c|c|c|}
\hline \multicolumn{6}{|c|}{ Velocity (ft/s) } \\
\hline \multicolumn{2}{|c|}{ Sitka spruce; Alaska } & \multicolumn{2}{|c|}{ Western Hemlock; Alaska } & \multicolumn{2}{|c|}{ White birch; Michigan } \\
\hline ST 300 & $\mathrm{HM} 200$ & ST 300 & HM 200 & ST 300 & $\mathrm{HM} 200$ \\
\hline 11905 & 9678 & 12000 & 10007 & 14545 & 12019 \\
\hline 11111 & 9285 & 10870 & 8497 & 15152 & 12653 \\
\hline 10417 & 8596 & 11450 & 9318 & 14760 & 12467 \\
\hline 13393 & 11319 & 11538 & 9416 & 14706 & 11920 \\
\hline 12397 & 10696 & 12195 & 10072 & 14925 & 12445 \\
\hline 12848 & 10597 & 12000 & 9875 & 14085 & 11874 \\
\hline 12712 & 10499 & 12295 & 9547 & 14493 & 12314 \\
\hline 12500 & 10696 & 11858 & 9154 & 13468 & 11002 \\
\hline 13158 & 11056 & 12000 & 9810 & 14706 & 11822 \\
\hline 12195 & 10039 & 12397 & 9941 & & \\
\hline 11278 & 9186 & 11029 & 9088 & & \\
\hline 12931 & 10400 & 11111 & 9088 & & \\
\hline 11278 & 8990 & 11905 & 9843 & & \\
\hline 13274 & 10302 & 11111 & 8891 & & \\
\hline 10791 & 8661 & 10791 & 8727 & & \\
\hline \multicolumn{2}{|c|}{ Jack Pine; Michigan } & \multicolumn{2}{|c|}{ Ponderosa pine; Oregon } & \multicolumn{2}{|c|}{ Loblolly pine; Louisiana } \\
\hline ST 300 & $\mathrm{HM} 200$ & ST 300 & HM 200 & ST 300 & HM 200 \\
\hline 13468 & 10553 & 11080 & 8734 & 13158 & 10203 \\
\hline 13201 & 11013 & 11204 & 8403 & 13158 & 10203 \\
\hline 13072 & 9777 & 9132 & 7424 & 12500 & 10236 \\
\hline 13514 & 11188 & 11587 & 9191 & 12500 & 10367 \\
\hline 13514 & 10827 & 9639 & 7899 & 13889 & 10630 \\
\hline 12987 & 10849 & 9901 & 7474 & 14085 & 10663 \\
\hline 14235 & 11395 & & & 13699 & 10696 \\
\hline 13746 & 11658 & & & 13333 & 10728 \\
\hline 15152 & 12927 & & & 13514 & 10827 \\
\hline 13889 & 10871 & & & 14085 & 10860 \\
\hline 12308 & 10368 & & & 14085 & 11024 \\
\hline 12308 & 10389 & & & 14493 & 11188 \\
\hline 13889 & 12566 & & & 14085 & 11286 \\
\hline 13841 & 11242 & & & 14599 & 11286 \\
\hline 12821 & 10203 & & & 14286 & 11319 \\
\hline 14035 & 10892 & & & 14085 & 11319 \\
\hline 13841 & 11549 & & & 13889 & 11352 \\
\hline 13029 & 11494 & & & 14706 & 11385 \\
\hline & & & & 14706 & 11385 \\
\hline & & & & 14493 & 11450 \\
\hline & & & & 14286 & 11483 \\
\hline & & & & 14286 & 11549 \\
\hline & & & & 13889 & 11745 \\
\hline & & & & 14286 & 11844 \\
\hline & & & & 13699 & 11844 \\
\hline & & & & 14925 & 12041 \\
\hline
\end{tabular}

